\title{
Financial Literacy, Present Bias and Alternative Mortgage Products
}

\author{
John Gathergood \\ University of Nottingham, School of Economics \\ Network for Integrated Behavioural Science \\ Jörg Weber ${ }^{\dagger}$ \\ University of Nottingham, School of Economics \\ Centre for Decision Research and Experimental Economics \\ Network for Integrated Behavioural Science
}

January 2017

\begin{abstract}
Choosing a mortgage is one of the most important financial decisions made by a household. Financial innovation has given rise to more complex mortgage products with back-loaded payments, known as 'Alternative Mortgage Products' (AMPs), or 'Interest-Only Mortgages'. Using a specially designed question module in a representative survey of UK mortgage holders, we investigate the effect of consumer financial sophistication on the decision to choose an AMP instead of a standard repayment mortgage. We show poor financial literacy and present bias raise the likelihood of choosing an AMP. Financially literate individuals are also more likely to choose an Adjustable Rate Mortgage (ARM), suggesting they avoid paying the term premium of a fixed rate mortgage.
\end{abstract}

Keywords: mortgages, financial literacy, present bias, alternative mortgage products JEL Codes: D10, D12, G21

\footnotetext{
* Corresponding author. Email address: john.gathergood@nottingham.ac.uk.

$\dagger$ Email address: joerg.weber@nottingham.ac.uk.

We would like to thank the editor and two anonymous referees for their helpful comments and suggestions. We would also like to thank João Cocco, Michael Haliassos, Charles Sprenger, Andreas Fuster, Abigail Barr and Robin Cubitt for their comments on earlier versions of this paper. Further thanks to conference participants at the Network for Integrated Behavioral Science Household Finance Conference April 2014, SABE Workshop July 2014, Rotterdam Household Finance Conference September 2014, Royal Economic Society Annual Conference 2015 and the 'Consumer Choice in Mortgage Markets' Conference, Imperial College London 2016. We acknowledge research funding which contributed towards this work under ESRC grants RES-061-25-0478 and ES/K002201/1 (Network for Integrated Behavioural Science). The authors would like to thank YouGov for incorporating questions into their household survey and making the data available for the purposes of this research project.
} 


\section{Introduction}

Since the onset of the financial crisis much controversy has surrounded innovations in the mortgage market. Mortgage provision is important for households - most households purchase a home during their lifetime and most purchases are funded by mortgage loans. For the typical household, a mortgage loan is the largest debt in the household's portfolio and is secured against the household's most valuable asset - the family home. The choice of type of mortgage used to finance a house purchase is a crucial decision for households, which has attracted much interest from policymakers.

The increase in mortgage lending during the 2000s was associated with the emergence of new types of mortgages, known as 'Alternative Mortgage Products' (AMPs). These innovative mortgage products offered new opportunities for households to purchase a home via a mortgage with much lower up-front costs. The key feature of an AMP is that payments cover only the interest due, or in some cases for an initial period, payments are less than the value of the interest due. Hence, the principal on the mortgage does not decline (it is "nonamortizing'), or may actually initially increase.

While consumers may use an AMP to smooth non-housing consumption over time when faced with expected income growth, consumers lacking financial sophistication may choose an AMP by mistake or due to a bias towards higher initial consumption. It is widely accepted that mortgage market failure has played an important role in mortgage decisions in the subprime mortgage market in the US (Mayer et al., 2009; Bernanke, 2010; Einav et al., 2012; Gerardi et al., 2013; Ghent, 2015). Cocco (2013) uses UK data to show many consumers use AMPs in a manner consistent with consumption smoothing. However, he also speculates that the greater complexity of AMPs together with poor consumer financial sophistication may lead some consumers to "fail to recognize that the lower initial mortgage payments imply larger future loan balances outstanding", and that "the lower initial payments are particularly appealing to myopic borrowers who put relatively little weight of the future.” (p. 1667).

In this paper, we investigate the role of consumer financial sophistication in the choice between an AMP and a standard repayment mortgage (SMP), and also the choice between a fixed and an adjustable rate mortgage (FRM and ARM). We focus on two dimensions of consumer sophistication: understanding of the financial components of mortgage products (commonly referred to as 'financial literacy') and time preferences for consumption now or in the future, i.e. whether consumers have high discount rates or show a 'present bias' for consumption due to an underlying self-control problem. In the UK, the context of this study, 
AMPs have been an important type of mortgage product since the early $1990 \mathrm{~s}^{3}$. At the same time, default rates are substantially higher among households with AMPs, and a sizeable proportion of current AMP holders may not be able to repay their mortgage principal at maturity (Financial Conduct Authority, 2013).

The environment for our research is an extensive individual level consumer survey conducted in 2013 into which we incorporate a series of bespoke questions to measure financial literacy and present bias. We configure the financial literacy questions to focus on mortgage choices to provide an objective measure of respondents' understanding of core concepts related to mortgage vehicles: the accrual of interest over time, simple interest calculations, interest compounding and the absence of principal repayments in an AMP. Our financial literacy questions do not require complex calculations, but do require a sound understanding of the core concepts embodied within each question, e.g. interest compounding. From these we discover that over two thirds of respondents understand that mortgages with longer maturities involve greater accrued interest and a similar proportion can make a simple interest calculation. But we also find that only half understand the concept of compound interest and fewer than $40 \%$ can correctly identify an AMP from a SMP.

We also insert a series of questions which have been developed in the recent applied behavioral economics literature to distinguish time preferences with respect to present bias and patience in survey settings. These traits may be important for understanding mortgage choices and are important controls in our econometric model. Both present-biased consumers as well as consumers with high discount rates may prefer AMPs because of the minimal upfront costs. Individuals with high discount rates put little weight on the future; they find the lower initial payments of AMPs appealing as they allow higher present consumption. But in the case of present bias the preference for AMPs arises because of underlying self-control issues and a consequent overweighting of present consumption (Laibson, 1997) ${ }^{4}$.

We empirically model the relationship between financial literacy, behavioral characteristics and mortgage choices. Financial literacy may arise endogenously with

\footnotetext{
${ }^{3}$ In our representative sample of UK mortgage holders, AMPs constitute around one quarter of UK mortgages and are held for the full value of the mortgage loan.

${ }^{4}$ In addition, a more impatient individual may be less willing to invest to the acquisition of financial literacy (Meier \& Sprenger, 2013). They are also more likely to face binding liquidity constraints as they desire higher consumption early in life. As Cocco (2013) acknowledges, agency problems like those modelled in Inderst \& Ottaviani (2012) may also play a role and AMPs may be sold predominantly to consumers with lower financial literacy or behavioral traits such as present bias. Hence, in this example, failing to control for time preference, the underlying determinant of both financial literacy and the choice of an AMP, will bias estimates of the relationship between financial literacy and mortgage choice.
} 
mortgage choices if individuals learn from their mortgage market experience. We therefore adopt an instrumental variable model to control for this potential endogeneity. In our econometric model we instrument current financial literacy with early life mathematical ability, following Jappelli \& Padula (2013). Mortgage choices may also arise due to affordability and credit constraints, which might correlate with financial literacy, hence we control for household income, income volatility and whether the household faces credit constraints. We also include a range of controls capturing mortgage characteristics as well as fixed effects for the year of mortgage origination. We further test the robustness of our results across samples of high and low income households, young and old households, and also to the sub-sample of households who recently made a mortgage refinancing decision. Choice of an AMP can also arise because households extrapolate past house price growth rates into the future; choice of an ARM may arise because the term premium is high. We test these conjectures in further robustness models. We also explore interaction effects between financial literacy and present bias.

Our results show that financial literacy and consumer behavioral traits are important determinants of mortgage choices. Poor financial literacy raises the likelihood of choosing an AMP. A decrease in financial literacy of one-point on our five-point scale raises the likelihood of an individual holding an AMP by around 53\%. We show that this result does not arise due to reverse causality or simultaneity when using instrumental variable (IV) estimation. Our results also show that present bias is strongly related to AMP holding, even when controlling for patience. This suggests that the preference for an AMP due to presentbias may arise because of an underlying self-control issue. This supports the contention of Cocco (2013) that myopic consumers are more likely to choose AMPs.

Our results also show that financial literacy increases the likelihood of choosing an adjustable rate mortgage compared to a fixed rate mortgage. A one-unit increase in literacy increases the likelihood of holding an ARM by around 22\%. We find no relationship between present bias, patience and the choice between ARM and FRM. We show that the term premium is a significant predictor of choosing an ARM, supporting the results of Koijen et al. $(2009)^{5}$. However, we also show that only financially literate consumers realize the added cost of paying the term premium of a fixed rate mortgage.

\footnotetext{
${ }^{5}$ The authors provide evidence to show that long-term bond risk premia, i.e. the term premium, is an important predictor of ARM choice. When the term premium is high, ARMs are more attractive because FRM payments are higher.
} 
We know of no prior US or UK work on the interplay between financial literacy, present bias and choices over mortgage repayment type and interest rate type. For Dutch households, two recent studies have examined financial literacy and mortgage choices. In the Dutch context the characteristics of alternative mortgage products and mortgage holders are quite different to the US or UK setting (Cox et al., 2015; van Ooijen and van Rooij, 2016). The majority of 'interest-only' mortgages incorporate a linked investment account, which makes them very similar to a repayment mortgage in the sense that initial payments include a contribution to the pay down the principal. There are also tax advantages to using an AMP (with or without a linked investment product). As Cox et al. (2015) show, households holding AMPs are typically more likely to be educated, have higher average incomes and higher average wealth. Both studies find individuals with better financial literacy are more likely to choose an AMP. Using US data, other studies related to our work show individuals with poor understanding of portfolio risk are more likely to withdraw housing equity (Duca and Kumar, 2014). Gerardi et al. (2013) find poor numerical ability in math tests predicts the likelihood of mortgage default.

Our findings contribute to the literature on the determinants of mortgage choices, in particular the choice between AMPs and SMPs (LaCour-Little and Yang, 2010; Piskorski and Tchistyi, 2010), but also the choice between ARMs and FRMs (Stanton and Wallace, 1999; Campbell and Cocco, 2003; Koijen et al., 2009). We also contribute to the literature on financial literacy by developing a new set of questions that measure literacy with respect to understanding central features of mortgage contracts. Our results are consistent with the broader financial literacy literature which shows the effects of poor financial literacy on a broad range of financial choices, including retirement savings, stock market participation and use of consumer credit (Guiso and Jappelli, 2005; Lusardi and Mitchell, 2007a, 2007b, van Rooij et al., 2011a, 2011b; Disney and Gathergood, 2013; Lusardi and Mitchell, 2014).

Our results are also important for the broader literature on present bias and self-control issues, which has shown that these are important factors for individual choice, both theoretically (Laibson, 1997) and empirically, for example for choices in retirement savings and in the labor market (DellaVigna and Malmendier, 2004; Ameriks et al., 2007; Busse et al., 2013). We also contribute to the expanding literature on investigating behavioral characteristics in representative surveys (Ameriks et al., 2007; Dohmen et al., 2010; Burks et al., 2012), as well as the potential interaction between time preferences and financial literacy (Meier and Sprenger, 2013).

The remainder of this paper proceeds as follows. In Section 2, we describe the evolution 
of AMPs in the UK mortgage market and in Section 3 the motivation behind our survey design, the survey instruments that we use plus initial results on characteristics of individuals by mortgage type. Section 4 describes our econometric modelling strategy. Following that, Section 5 presents econometric results from a variety of econometric models which reveal the impact of financial literacy and present bias on mortgage choice. We discuss our results and conclude in Section 6.

\section{The UK Mortgage Market}

The UK mortgage market includes a significant share of AMP products with several characteristics that make it particularly interesting for the study of consumer mortgage choice. AMPs have been common in the UK since the early 1990s and were widely chosen by consumers (in our data $22 \%$ of mortgage holders have an AMP). There are three distinctive features of AMPs in the $\mathrm{UK}^{6}$. First, they are used to finance the entire mortgage balance over the full term of the mortgage. For example, in our data there are no instances of individuals holding both SMPs and AMPs, in contrast to the US market (Mayer et al., 2009). This implies that, compared to the US, in the UK market AMPs are typically held at higher loan-to-value (LTV) limits. Second, there are no conforming loan limits that dictate loan size, loan characteristics or the relationship between the two in the UK mortgage market. That means that AMPs are typically available under similar conditions as SMPs, e.g. with the same minimum deposits or leverage ratios. Third, unlike the Dutch market, most AMPs are sold without linked savings accounts ${ }^{7}$. A review of AMPs in the UK can be found in Cocco (2013), who examines the use of AMPs by individual mortgage holders in a sample of UK consumers beginning in 1993. For a recent review of international differences in mortgage markets see Badarinza et al. (2016).

\footnotetext{
${ }^{6}$ Within the US, AMPs developed during the early 2000s as add-on products for conforming mortgages and incorporated limited or no amortization. In some cases, they incorporated negative amortization up to specific loan-to-value (LTV) limits, i.e. initial mortgage payments did not cover interest charges for some period. Some AMPs were coupled with a 'teaser' interest rate, implicitly assuming house price growth would exceed negative amortization ahead of the next mortgage refinancing point. The wide variety of AMP products offered in the US market is reviewed in Mayer et. al (2009).

${ }^{7}$ Historically, AMPs were commonly sold alongside stock-market linked investment vehicles designed to accrue the principal payable at maturity. However, alleged mis-selling of endowment mortgages based on unrealistic returns resulted in the regulator demanding endowment mortgage providers to provide compensation to holders of endowment-linked mortgages in the early 2000s (see Severn, 2008 for a detailed review). The regulator imposed compensation payments to make up for projected shortfalls in the value of accrued endowments. One impact of the mis-selling episode has been that mortgage providers no longer recommend endowment products and instead sell interest-only mortgages with no associated investment vehicles. In our dataset, two thirds of AMP holders report they have no linked investment product or other investment which they intend to use to repay the outstanding principal due at maturity.
} 
Previous studies have raised concerns about mortgage choices by UK consumers. The 'Miles Report' (Miles, 2004) chronicles the innovation and features of the UK market, but also raises the issue of consumer misunderstanding of mortgage products. In particular, Miles (2004) argues that many consumers base their mortgage choice on initial payments only and not the longer-term horizon. The report also shows that consumers tend to focus on initial costs, but not on expectations of future interest movements, although it argues that forwardlooking consumers should factor in the likely future cost of different mortgage product types when making their borrowing decision.

FRMs in the UK mortgage market are notably different from those in the US in that the interest rate is fixed only temporarily, typically for a period between 2 and 5 years and only rarely longer than this. Therefore, borrowers taking on FRMs are exposed to much more interest rate risk compared with the US market where the rate is fixed for the full term of the mortgage. FRMs reset to a Standard Variable Rate (SVR) at the end of the fixed period, which is typically much higher than the fixed rate (for further institutional details on the functioning of FRM products in the UK see Miles, 2004, Section 2).

\section{Survey Data}

To investigate the role of financial literacy and present bias in mortgage choice, we commissioned a special module in a survey of UK consumers. Our survey is the YouGov Debt Tracker, a cross-sectional survey of UK households, conducted quarterly by the market research company YouGov. We use the August 2013 wave which surveys a representative sample of 2,000 UK households drawn from YouGov's panel of 350,000 households ${ }^{8}$.

\subsection{Survey Sample Characteristics}

Summary statistics for the survey sample are presented in Table 1. Sample characteristics are very similar to those of larger official UK surveys ${ }^{9}$. In total, there are 1,974 households

\footnotetext{
${ }^{8}$ The survey is conducted via the internet and special provisions for non-internet users are made to achieve a representative sample (we later show that average levels of income, assets, debt and mortgage types in our data are very close to official data). The core Debt Tracker survey comprises approximately 80 questions that cover demographics, finances, labor market situation, education, financial product use and housing. The survey provides information on housing tenure and value plus details of the mortgages held.

${ }^{9}$ The summary characteristics of the sample shown in Table 1 closely align with those from the official 'Wealth and Assets Survey' (WAS; the largest UK survey of household finances interviews approximately 30,000 households per annum, undertaken by the Office for National Statistics). In the 2012-2014 wave of WAS, the most recent available, $62 \%$ of main respondents report as employed with average household income of $£ 33,500$. Among mortgage holders, average household income is $£ 46,400$; self-reported property value $£ 194,600$ and outstanding mortgage debt $£ 85,700$; the average loan-to-income ratio is 2.18 and loan to value ratio is 0.51 .
} 
in our sample, of which $32 \%$ are mortgage holders, $32 \%$ are outright homeowners and $36 \%$ are renters. Mortgage holders are typically in midlife, better educated, more likely to be employed. Mortgage holders report, on average, the highest mean and median incomes of all subgroups. Renters are typically younger than mortgage holders and outright owners are typically older (79\% of outright owners are aged over 55). Compared with whole sample characteristics, mortgage holders are more likely to be married (77\% compared to $64 \%$ in the sample), have dependent children (36\% compared to $20 \%)$ and to be in employment ( $85 \%$ compared to $59 \%)^{10}$.

We also construct a measure of whether the household is credit constrained, which may be an important variable in explaining mortgage choices. We identify credit constrained households with a set of survey questions from which we create a $1 / 0$ dummy variable to denote credit constraints. This dummy is 1 if respondents answer 'yes' to at least one of four statements that describe whether they or their partner recently had a credit line withdrawn, a credit line reduced, have exceeded their credit line, or currently cannot get new credit. A household is also classified as credit constrained if respondents state that applications to unsecured credit products have been turned down recently.

In addition, we also construct a measure of income volatility in the sense of recent experienced income loss. We use four questions to create a create a dummy variable that is 1 if the respondent states that they or their partner have experienced reductions in income arising from changes in labor or non-labor income or changes in employment status recently.

We focus on the 632 mortgage holders in the sample and divide this group by mortgage repayment type and interest rate type. Summary data by mortgage type are shown in Table $2^{11}$. In our sample $78 \%$ of mortgage holding households hold a SMP and 22\% hold an AMP. 53\% hold an ARM and 47\% hold a FRM. There are some demographic differences between holders of AMPs and SMPs. Compared with households who hold a SMP, holders of AMPs are typically less likely to have a household head in employment and have lower income (average income among AMP holders is approximately 10\% lower than among SMP

These values are close to those in Tables 1 and 2, suggesting no large differences between our relatively small survey sample and the much larger WAS sample.

${ }^{10}$ These sample summary values closely match those of the 'Understanding Society' survey, from which equivalent statistics are: to be married 65\%; have dependent children $22 \%$; be in employment $61 \%$, average household income $£ 33,200$.

${ }^{11}$ Respondents are asked whether they hold a 'repayment mortgage' or an 'interest only' mortgage. If choosing interest only, they are then asked the type of interest only mortgage they hold (linked endowment, linked ISA/PEP, pension or no linked repayment vehicle). 
holders). The differences in the average mortgage size of the two groups are small: AMP and SMP holders have similar average property values and outstanding mortgage amounts. The average loan-to-income ratio (LTI) among holders of AMPs is also similar compared to holders of SMPs (11\% difference), consistent with the UK data sample used by Cocco (2013). By way of contrast there are no notable differences in characteristics between the FRM and ARM groups.

\subsection{Financial Literacy Questions}

We first describe the design of our survey questions which measure financial literacy. We designed a specific set of questions relating to mortgage products. In our view, in the analysis of the relationship between financial literacy and financial choices, it is essential that the measure of financial literacy used by the researcher is relevant for the financial choices modelled $^{12}$. For example, van Ooijen and van Rooij (2016) use Dutch data to show that mortgage choices are related to a measure of debt literacy based on understanding of mortgages, but unrelated to a generic financial literacy measure. It is also essential that the measure of financial literacy allows the researcher to judge better and worse levels of financial understanding in an objective way.

In designing these questions, we seek to achieve two objectives. First, to construct an objective measure of the extent to which an individual understands the key concepts in finance relevant for mortgage choice, and second, to do so in a design which is not mathematically complex and can be incorporated in a survey setting. The literature has documented that basic, or 'core', financial literacy varies in the population and that variation in correct responses to relatively simple questions about finance can explain significant heterogeneity in observed choices related to consumer credit and debt (Lusardi and Tufano, 2015; Disney and Gathergood, 2013), retirement savings (Lusardi and Mitchell, 2007a, 2007b; van Rooij et al., 2011a) and stock market participation (Guiso and Jappelli, 2005; van Rooij et al., 2011b). These studies typically use question-based instruments to measure individual understanding of, for example, compound interest or minimum payments on a credit product. Multiple-choice questions with relatively low mathematical requirements are

\footnotetext{
${ }^{12}$ For example, financial literacy questions framed within the context of retirement saving decisions (for instance focusing on the concepts of real vs nominal returns and annuity returns) are not appropriate for analyzing decisions relating to, for example, consumer credit and debt for which those concepts are not integral. Some concepts, such as interest compounding, are common to understanding of a wide variety of products, but should be incorporated into questions which focus on the particular domain of interest, in our case mortgage choice, to avoid framing bias.
} 
used to avoid the financial literacy questions resembling a math test, or requiring infeasible calculations within the context of a consumer survey.

We adopt the same approach of question-based measures for the design of our financial literacy questions. We include four questions to the survey that aim to measure respondents' ability to make informed decisions specifically with regards to mortgage choice, which we brand 'mortgage financial literacy'. Each question was framed in the context of a particular dimension of typical mortgage contracts and constructed using a multiple-choice format. In the online survey, respondents could view answers to each question on screen with the option of choosing one. We also designed the implementation of the questions within the survey to avoid priming, anchoring and default effects ${ }^{13}$.

The four questions are (correct answers in italics):

1. Suppose a 15-year mortgage and a 30-year mortgage have the same Annual Percentage Rate and the same amount borrowed. The total amount repaid will be: i) Higher for the 15-year mortgage; ii) Higher for the 30-year mortgage; iii) The total amount repaid on both mortgages will be the same; iv) Don't know

2. Suppose you owe $£ 50,000$ on a mortgage at an Annual Percentage Rate of $6 \%$. If you didn't make any payments on this mortgage how much would you owe in total after one year? i) Less than $£ 50,000$; ii) $£ 50,000$ - $£ 54,999$; iii) $£ 55,000-£ 59,999$; iv) $£ 60,000$ - $£ 64,999$; v) More than $£ 65,000$; vi) Don’t know

3. Suppose you owe $£ 100,000$ on a mortgage at an Annual Percentage Rate of $5 \%$. If you didn't make any payments on this mortgage how much would you owe in total after five years? i) Less than $£ 120,000$; ii) Between $£ 120,000$ and $£ 125,000$; iii) More than $£ 125,000$; iv) Don’t know

4. Suppose you owe $£ 200,000$ on a mortgage with at an Annual Percentage Rate of $5 \%$. If you made annual payments of $£ 10,000$ per year how long would it take to repay the whole mortgage? i) Less than 20 years; ii) Between 20 and 30 years; iii) Between 30

\footnotetext{
${ }^{13}$ In particular, we adopted the following approach. First, the survey questions are designed to include a 'don't know' answer in order to distinguish incorrect answers from self-aware consumers who recognize they do not know the answer, second the financial literacy questions are placed first, before the questions on behavioral characteristics, in order to avoid justification biases, third the question on the instrument (achievement in math education in school) is placed before the financial literacy questions in order to avoid priming effects arising from perceived performance on the questions, fourth the survey is administered online using a visual interface so as to reduce biases from ordering, finally respondents indicated their answers using radio buttons, with the buttons initially blank in order to avoid anchoring / default effects.
} 
and 40 years; iv) The mortgage would never be repaid; vi) Don't know

Performance of survey respondents on our questions confirms our prior that the questions are increasing in difficulty. Table 3 shows a breakdown of answers. The first two questions test very basic understanding of interest rates and how to make a simple interest calculation. In the whole sample $81 \%$ of respondents answer the first question correctly, this falls to $66 \%$ for the second. For the third question (interest compounding) and fourth question (amortization) these correct answer rates fall to 51\% and 37\%.

Columns 2 and 3 show unconditional comparisons of performance of subjects on these questions by their mortgage repayment type and interest rate type. The p-values from a test for the equivalence of means show that a lower proportion of AMP holders answers each of the questions correctly compared with SMP holders, with large differences on even the first question (28 percentage points). Overall, AMP holders answer on average approximately one and a half questions correctly, compared with two and a half for SMP holders. By contrast, the differences in correct answer rates across FRM and ARM holders is much narrower, with an overall difference of just 0.22 points on the five-point index, significant at the $5 \%$ level.

A detailed breakdown of individual characteristics by mortgage literacy score is provided in Table 4 . The table shows that mortgage financial literacy strongly correlates with choice of repayment type. Among the 138 individuals with a score of 4 out of 4 , only $12 \%$ hold an AMP compared with 67\% among the 63 individuals with a score of 0 out of 4 . The unconditioned correlation between mortgage literacy score and the likelihood of holding an AMP is -0.88. As might be expected, individuals with better mortgage literacy scores typically have a higher education leaving age, higher household income and higher property values. There is no clear relationship between mortgage financial literacy score and mortgage interest rate, LTI or LTV.

The literature recognizes that financial literacy arises endogenously with financial choices ${ }^{14}$. Financial literacy may be correlated with individual characteristics we do not observe directly (such as human capital) and other elements of an individuals' financial situation (such as asset holding). Also, reverse causality may be at play whereby an individual's mortgage choice affects their subsequent mortgage financial literacy through learning mechanisms. This may be relevant in our scenario: for example, the choice of taking

\footnotetext{
${ }^{14}$ Christiansen et al. (2008), Lusardi \& Mitchell (2007a, 2007b) and Behrman et al. (2012) show that models that do not control for correlated errors typically underestimate the effect of financial literacy on wealth accumulation.
} 
a SMP as opposed to an AMP may lead to consumers acquiring information on mortgage amortization through their mortgage statements, information which they would not receive had they taken an AMP, and so improve their performance on our financial literacy questions.

To address this, we also inserted into the survey design a question which allows us to develop an instrument for self-reported financial literacy. The candidate instrumental variable should be correlated with the instrumented variable (the financial literacy score), but be exogenous to mortgage choice and unrelated to the unobservable characteristics which may be related to mortgage choice. The instrument that we use has been suggested by Jappelli \& Padula (2013), who demonstrate theoretically that pre-labor market entry financial literacy endowment is a valid instrument in estimations of financial literacy. Based on this, we include their suggested question in the survey:

- When you were at primary school aged 10 how did you perform in maths compared to other children in your class? i) Much better than average; ii) Better than average; iii) About the same as average; iv) Worse than average; v) Much worse than average

In the UK education system, 10 is the age before high school entry and hence before students can self-select into subjects of interest e.g. economics and finance. From answers to this question we create a primary-school math level score ranging from one ('much worse') to five ('much better'). We use this as our instrument in IV estimates.

\subsection{Measures of Behavioral Characteristics}

In addition to the financial literacy questions, we include survey instruments to proxy a variety of behavioral characteristics. We focus on present bias and patience. Researchers seeking to measure behavioral characteristics typically use incentivized laboratory experiments involving choices for money. However, a laboratory setting necessarily limits the available subject pool. Consequently, recent research has seen the development of a series of survey instruments. These have been shown to correlate very closely with those obtained in laboratory studies (Vischer et al., 2013; Ameriks et al., 2007; Dohmen et al., 2010, 2011; Burks et al., 2012).

First, we elicit present bias using Likert scale responses by which respondents associate or disassociate themselves with a short statement describing 'impulsive' consumption behavior on a five-point scale from 'agree strongly' to 'disagree strongly'. The statement is:

- "I am impulsive and tend to buy things even when I can’t really afford them."

This question proxies self-control issues in the sense of 'present bias', which we also use 
in Gathergood (2012) and Gathergood \& Weber (2014). Respondents are asked by how much they can see themselves preferring instantaneous gratification even when it is suboptimal, conceptually similar to the self-control measure developed by Ameriks et al. (2007). We create a binary variable that we label 'Present biased', taking the value of one if the respondent answers 'tend to agree' or 'agree strongly' and zero. We show below that our measure of present bias predicts credit card and other high cost debt holding as well as low holdings of liquid savings. The literature has shown that these financial behaviors are associated with present bias.

Second, we elicit patience. A measure of patience is particularly important for our analysis, because it allows us to distinguish self-control issues in the form of present bias from high discount rates (impatience) ${ }^{15}$, such as in the quasi-hyperbolic discounting model of Laibson (1997). We do not assume that individuals in our data have preferences which are best represented by quasi-hyperbolic discounting, but show in our results these two distinct elements of time preferences are revealing in understanding choice behavior. Answers to the questions on patience and present bias are uncorrelated (the correlation coefficient between these two variables is -0.06), implying the two instruments capture distinctly different components of time preference.

We adopt a widely used short proxy for patience as described in Dohmen et al. (2010). The authors insert this measure of patience into the German Socio-Economic Panel to investigate the relation between risk aversion, patience and cognitive ability. The question is:

- "How do you see yourself: are you generally an impatient person, or someone who always shows great patience? Answers are coded on an 11-point scale, with 0 referring to 'very impatient' and 10 to 'very patient'."

In a follow-up study the authors conduct incentivized time preference experiments on the survey subject pool and find that answers to the survey proxy provide very similar estimates as more complex elicitation procedures, such as multiple price lists (Vischer et al., 2013). They also show that answers to this survey question predict impatience even when controlling for impulsiveness.

\footnotetext{
${ }^{15}$ The two concepts are theoretically distinct in $\beta-\delta$ models of quasi-hyperbolic discounting to distinguish between linear (time-consistent) discounting (the $\delta$ part) and present bias (the $\beta$ part), such as in Laibson (1997). This distinction may be important empirically: mortgage choices might be explained by high discount rates, implying that consumers make time consistent choices over time but simply prefer the higher current consumption offered by an AMP. However, if mortgage choices are explained by impulsive behavior, there may be potential for consumers to suffer regret over the choices they make and for these choices to be considered to be sub-optimal.
} 
Third, we measure risk attitude. Campbell \& Cocco (2003) show that more risk averse households may prefer fixed rate mortgages. Individuals with greater risk aversion may also shy away from AMPs due to the underlying uncertainty of repaying the principal. Alternatively, risk averse households may exhibit a preference for AMPs if they are concerned with future income streams and the higher present repayments of SMPs. Our measure of risk attitude is again based on a question developed by Dohmen et al. (2010):

- "How do you see yourself: are you generally a person who is fully prepared to take risks or do you try to avoid taking risks? Please tick a box on the scale, where the value 0 means: 'unwilling to take risks' and the value 10 means: 'fully prepared to take risk'."

Summary data for behavioral characteristics of respondents are described in Table 5. The average numerical value for patience among all mortgage holders on the $0-10$ scale is 5.56 with a standard deviation of 2.55. The average level (and standard deviation) of patience is very similar across mortgage repayment type and interest rate type. AMP holders are on average slightly more patient than SMP holders and FRM holders are more patient than those with ARMs, but a t-test fails to reject the null hypothesis that these values are equivalent. There is more notable variation across mortgage type groups in the degree of present bias. The table shows a breakdown of each answer to the present bias question by mortgage type and of our constructed dummy variable ('Present biased' =1). In the sample of all mortgage holders, $13 \%$ of respondents are in the present biased category. A breakdown by repayment type shows that holders of AMPs are twice as likely to be present biased than SMP holders (19\% compared with $11 \%$ ), this difference is statistically significant at the $1 \%$ level.

Is there evidence to validate that responses to this question elicit present bias, or might it capture some other individual behavioral trait? The existing literature shows, both theoretically and empirically, that present bias induces higher levels of credit card debt and lower savings (Laibson et al., 2003; Meier and Sprenger, 2010; Heidhues and Köszegi, 2010; Laibson, 1997). To explore this, we relate our measure of present bias to occurrences of high cost credit and savings. We estimate a series of regression models that relate our behavioral measures to the likelihood and levels of consumer debt and liquid savings.

In Columns 1 and 3 of Appendix Table A1 we estimate probit models where the dependent variables are indicator variables for whether the individual holds high cost credit 
and savings, respectively ${ }^{16}$. Among those who hold a balance on at least one consumer credit product and have savings, respectively, we estimate the linear relationship between the log of the respective (non-zero) balances and our behavioral measures (Columns 2 and 4). The coefficient on the present biased dummy variable is statistically significant at the $1 \%$ level in all models except in Column 2 (the log of high cost credit), where the p-value is 0.016 . Present bias raises the likelihood of holding high cost credit by $40 \%$ (average marginal effect of 0.188 divided by baseline probability 0.471 ) and decreases the likelihood of holding savings by $39 \%(0.198 / 0.506)$. We also include the patience variable in each model and find, in each case, the coefficient on this variable is not statistically significant at the $5 \%$ level or less. This evidence is in line with the prior literature and suggestive (without proving) that our survey measure captures present bias in individual time preferences.

\section{Econometric Models}

Our main interest is in estimating the relationship between financial literacy, behavioral characteristics and mortgage choices. As we describe earlier, estimating the relationship between financial literacy and mortgage choices requires a strategy to account for the potential endogeneity of financial literacy to mortgage market experience. We adopt an Instrumental Variables (IV) strategy in which financial literacy is instrumented by our measure of earlylife math performance at school.

Specifically, we first take a fundamental model of the determinants of mortgage type, closely following Cocco (2013) in which mortgage choices are explained by a vector of covariates incorporating life-cycle characteristics: age, demographics (gender, marital and family status, employment status, household income, income volatility) and also credit constraints. We then add our instrumented financial literacy index to this model. In subsequent specifications, we then test the sensitivity of our results to additional covariates which control for our measures of behavioral characteristics and features of the mortgage contract (level of debt, loan-to-value ratio, loan-to-income ratio and mortgage interest rate) ${ }^{17}$ as well as year or mortgage origination fixed effects. The survey data includes the year in which the household took out their current mortgage. Approximately $40 \%$ of all mortgages in our data originated

\footnotetext{
16 'High cost credit' is defined as holding two credit/store cards or more, and/or holding a payday loan, pawn broker loan or home collected credit. 'Savings' are liquid savings in excess of $£ 250$.

${ }^{17}$ Following Cocco (2013) and Koijen et al. (2009), we control for LTV and LTI ratios. We also control for the level of mortgage debt as this might increase with financial literacy (as the consumer faces higher stakes) and also condition for the repayment type in the interest type regression, and vice versa.
} 
in the last four years. It is important to control for characteristics of the mortgage as it could be the case that financial literacy is increasing in the level of debt, because the stakes involved are higher, or that there could be cross-effects between the two mortgage types we consider in the analysis. With two dimensions of mortgage choice as our dependent variables, the models we estimate are:

$$
\begin{array}{ll}
\operatorname{Pr}(\mathrm{Y}=1)=\Phi\left(\alpha_{0}+\alpha_{1} f l+\alpha_{2} b+\alpha_{3} m+\mathbf{X}^{\prime} \beta\right) & \text { (Equation 1) } \\
f l=\alpha_{0}+\alpha_{1} \text { math }+\alpha_{2} b+\alpha_{3} m+\mathbf{X}^{\prime} \beta+u & \text { (Equation 2) }
\end{array}
$$

Equations 1 and 2 are jointly estimated using maximum likelihood. $Y$ represents a vector of mortgage type variables (dummy variables for AMP vs. SMP and ARM vs. SRM); $f l$ is the instrumented financial literacy score, instrumented in the first stage regression with the instrument math (the math performance at school index variable), $b$ is a vector of behavioral variables, $m$ is a vector of mortgage contract variables, as described above and $\mathbf{X}^{\prime}$ is the vector of socio-economic and demographic controls, also as described above. In further analysis, we include the regional unemployment rate, the regional median 3-year growth rate of house prices and 5-year term premium, all at the year of origination.

We further test the robustness of our model estimates to a variety of alternative econometric specifications. The choice of mortgage may be related to the affordability of the payment schedule (AMPs and ARMs have lower payments), which itself is determined by household income which correlates with financial literacy. Therefore, we test the robustness of our main results to sub-samples of high and low income households. Mortgage choice may be related to age, as older households may have more experiences that can affect their choices. We therefore estimate our models split at the median age. For some households, which originated their current mortgage some time ago our measure of financial literacy may be outdated, so we also test the robustness of our results by restricting the sample to households who recently took out their mortgage. In addition to these we also estimate specifications in which we exclude individuals with endowment mortgages (with a stock market linked investment) and exclude those who state 'don't know' to the financial literacy questions. Finally, we test for the existence of interaction effects between financial literacy and present bias. 


\section{Results}

\subsection{Econometric Results}

Our main results from econometric models in which the dependent variable is mortgage repayment type are shown in Table 6 (full results with all covariates are shown in Table A9). The dependent variable is a dummy variable taking the value of 1 if the mortgage held is an AMP and 0 if it is an SMP. Column 1 shows results from the parsimonious normative specification which only includes socio-economic control variables (including financial controls and credit constraints) and the instrumented financial literacy score. In the first-stage regression the single instrument, math level at a school, is positive and statistically significant at the $1 \%$ level (first-stage regression estimates and the non-instrumented probit results of the full model with all covariates are shown in Table A2). The F-statistics of the regression is 13.7, above the 'weak instrument' test critical value of 10 suggested by Stock \& Yogo (2005), though a Wald test of exogeneity fails to reject the null hypothesis of no endogeneity $(p=$ 0.937). Results show the coefficient on the instrumented financial literacy score is negative and statistically significant at the 1\% level. The marginal effect of -0.107 implies a one-unit increase in the instrumented financial literacy score lowers the probability of the mortgagee holding an AMP by 11 percentage points, or a 30\% decrease in the likelihood when evaluated against the baseline probability.

Model estimates in Column 2 show results from adding the behavioral characteristics variables to the Column 1 specification. The coefficient on the present biased indicator variable is statistically significant at the $1 \%$ level. The marginal effect of 0.131 implies a present biased consumer is 38\% more likely to hold an AMP. The coefficient on risk attitude is significant at the 5\% level and negative. This may appear counter-intuitive as AMPs can appear to be a riskier choice. However, individuals who are risk averse may see lower initial payments of an AMP which would reduce the exposure of the household to the negative effects of income risk. Column 3 further includes controls for characteristics of the mortgage loan (which may arise endogenously with the mortgage type). Among these the ARM dummy is positive and statistically significant at the $1 \%$ level and the amount of mortgage debt is positive and significant at the 5\% level. Column 4 presents the full model shown in Equations 1 and 2. In this model the coefficient on the financial literacy score remains negative and statistically significant at the $1 \%$ level, the marginal effect implying a 1-unit increase in financial literacy lowers the likelihood of holding an AMP by 53\%. We perform likelihood ratio tests to evaluate whether models with added covariates increase the explanatory power 
relative to the baseline model in Column 1 . These are significant at the $1 \%$ level in each case. Table A10 in the Appendix show results of the likelihood ratio tests comparing all model specification against each other. These results show that our additional covariates significantly increase explanatory power in all cases.

Results from models in which the dependent variable is interest rate type are shown in Table 7 (first-stage regression estimates are shown in Table A2, full second-stage results are shown in Table A10). The coefficient on the instrument is positive and statistically significant at the $1 \%$ level. The Wald test of exogeneity rejects the null hypothesis of no endogeneity at the 5\% level in all specifications shown in Table 7. In Column 1 the coefficient on the instrumented financial literacy score is positive and statistically significant at the $1 \%$ level. The marginal effect from the coefficient of 0.115 implies a one-unit increase in financial literacy score raises the likelihood of the consumer holding an ARM by $23 \%$.

Results in Columns 2-4 show that none of the coefficients on the behavioral characteristics variables are statistically significant, but that holding an ARM is related to mortgage characteristics. The likelihood of holding an ARM is increasing with holding an AMP and with the loan-to-value ratio and decreasing in the loan to income ratio and mortgage interest rate. When behavioral and housing-related covariates are included in the full specification in Column 4 the coefficient on the financial literacy score remains statistically significant at the $1 \%$ level, with the implied effect of a one-unit increase in the financial literacy score now raising the likelihood of holding an ARM by 22\%, very similar in magnitude to the effect in Column 1. The likelihood ratio test statistics and p-values confirm that the addition of behavioral and housing variables increases the explanatory power of the models (see Table A11).

\subsection{Does 'Extrapolation Bias' Explain Mortgage Choices?}

In the next tables, we explore whether other behavioral channels drive mortgage choices, and also explore their relationship with financial literacy. First, we investigate whether extrapolation bias over house price trends at the point of choosing affects mortgage choice. Extrapolation bias is the tendency to overweigh recent trends when making decisions about the future. This bias may be important for mortgage choices. In particular, mortgagees might extrapolate past house price growth into the future and on that basis choose an AMP, anticipating that a lower loan-to-value ratio will be achieved through house price growth instead of principal repayments.

Our survey data includes details of the time at which the individual chose their current 
mortgage (in 2-3 year bands). The dataset also provides the four-digit postcode for the location of the survey respondent. There are 3,114 four-digit districts in the UK and we match house prices using official sales data ${ }^{18}$. We calculate the 3 -year and 5-year growth rate of median house prices in the postcode district of the individual survey respondent in the period before the mortgage was taken out. We then include this as an additional covariate in our IV probit model. If the house price growth variable is positive and significant in the model for mortgage repayment type, this would suggest mortgagees extrapolated past growth in the decision to choose an AMP over a SMP. We also match in regional unemployment rates at the time of origination to control for local economic conditions.

Results are shown in Table 8. Column 1 reports estimates for the mortgage repayment type model. The coefficient on the 3-year growth of median house prices is positive and statistically significant at the 5\% level. The marginal effect of 0.002 implies that a one standard deviation increase in the three-year median growth rate of median house prices (21\%) increases holding an AMP by approximately $21 \%$. We also replace the 3 -year growth rate with the 5-year growth rate with similar results (results not shown). This result provides support for the extrapolation bias hypothesis. The regional rate of unemployment is not statistically significant.

In Column 2 we show estimates from the interest rate type model. The coefficient on the 3 -year growth rate is also statistically significant, but only at the $10 \%$ level with a small marginal effect. The coefficient on the regional unemployment variable is negative and statistically significant at the $1 \%$ level, implying a one percentage point in the regional rate of unemployment lowers the likelihood of choosing an ARM by $6.9 \%$. The marginal effect on the extrapolation bias coefficient implies a one standard deviation increase in the growth rate of median house prices $(21 \%)$ raises the likelihood of holding an ARM by $8.3 \%$. This implies individuals are more likely to choose to take a FRM when unemployment is higher, potentially reflecting the impact of uncertain macroeconomic decisions on the decision to take a lower risk (but higher interest rate) mortgage ${ }^{19}$.

\footnotetext{
${ }^{18}$ In the UK, all prices for which houses and real estate are sold are recorded by the 'Land Registry'. This data is currently not available for Scotland and Northern Ireland, we therefore estimate the model of extrapolation bias for English and Welsh households, only.

${ }^{19} \mathrm{We}$ also estimate models with interaction terms between financial literacy and the 3-year median growth rate of house prices, and interaction terms between the present bias dummy variable and the 3-year median growth rate of house prices. We find no evidence for interaction effects in models in which repayment type is the dependent variable. In models of interest rate type, we find a negative interaction between financial literacy and the growth rate of house prices, implying that more financially literate households are less likely to hold ARM mortgages when house price growth is stronger. One reason for this interaction may be that more financially
} 


\subsection{Term Premium and Interest Rate Type Choice}

Another potential channel by which financial literacy affects mortgage choices is its effect on household responses to the term premium. Koijen et al. (2009) show that term premia are a significant predictor over holding ARMs: when the term premium is high, payments for FRMs are higher, making ARMs more attractive. We test this conjecture in Table 9 where we estimate the model for interest rate type including the term premium in the model (we exclude year of origination fixed effects which are collinear with the term premium variable in our data). We match in the five-year term premia calculated for the year of mortgage origination, as estimated by Malik \& Meldrum (2016). The coefficient on the term premium is positive and statistically significant at the $1 \%$ level, implying a $1 \%$ increase in the term premium raises the likelihood of choosing an ARM by $42 \%$. Importantly, financial literacy remains positive and statistically significant.

Households may require financial literacy to recognize the time varying costs of the term premium, and in Column 3 we include an interaction term between the term premium and financial literacy. We find that the coefficient on the interaction is positive and statistically significant at the $1 \%$ level, while the inclusion of the interaction leaves the main coefficient statistically not significant. Financial literacy remains positive and significant. These results indicate the term premium affects mortgage interest rate types only through the interaction with financial literacy - individuals with a zero-financial literacy score are no more likely to choose an ARM when the term premium is high, but individuals with higher financial literacy scores have an added likelihood of choosing an ARM when the term premium is high.

\subsection{Sensitivity and Robustness Tests}

\subsubsection{High and Low Income Households}

In this final section, we present results from additional models in which we test the sensitivity and robustness of our main results. First, we show the results estimated on subsamples of high/low income households. Income may be a confounding factor in the relationship between financial literacy and mortgage type if low income households, with lower average financial literacy, choose AMPs due to their lower initial repayments due to affordability constraints. In our model in Equations 1 and 2 we include income as a control within the set of socio-economic covariates. To further examine the sensitivity of our results to house- 
hold income, in Table A3 we report estimates of Equations 1 and 2 estimated separately on sub-groups of households separated by high/low income split at the median.

Results for the models which explain AMP/SMP holding in Columns 1 and 2 show the coefficient on the instrumented financial literacy score is negative and statistically significant in both models at the 5\% level. A Chow test for the equivalence of coefficients on the literacy score in the models in Column 1 and 2 cannot rejects the null of equivalence of coefficients $(p=0.516)$. The marginal effects on the estimated coefficients evaluated against the baseline predicted probabilities imply very similar effects across the models - a one-unit increase in financial literacy causing a 51\% reduction in the likelihood of holding an AMP among low income households and a 45\% reduction among high income households. This suggests that our results with regards to financial literacy are not biased by income effects. However, the results on the present bias show that the coefficient is only statistically significant for low income households, though a Chow test cannot reject the null of equivalence of coefficients $(\mathrm{p}=0.137)$.

Results for the models which explain ARM/FRM holding in Column 3 and 4 show the coefficient on the instrumented financial literacy variable is positive and statistically significant at the $1 \%$ level in Column 4 and positive in Column 3 but not statistically significant at the $10 \%$ level. Again, a Chow test cannot reject the null of equivalence of coefficients in Columns 3 and $4(\mathrm{p}=0.525)$. Again, these results indicate that the relationship between financial literacy and mortgage interest rate type is not driven by income effects.

\subsubsection{Younger versus Older Households}

Additionally, we show estimates by sub-samples of younger (age 18-44) and older (age 45 and above) households in Table A4. Results show that the relationship between financial literacy and holding an AMP is stronger among the young, though the coefficients on the financial literacy variables in the regressions containing samples of older and younger respondents are statistically significantly different from one another at only the $5 \%$ level $(\mathrm{p}=$ 0.042). Results in Columns 3 and 4 show differences in the coefficient estimate which are statistically significantly different $(\mathrm{p}=0.000)$, with the marginal effect from the positive coefficient on the financial literacy variable among the young sample regression implying a one-unit increase in financial literacy raises the likelihood of holding an ARM by 39\%. These results show that financial literacy is more important for the choices of the young. One explanation for this is that as households age and gain experience in mortgage decisions their financial literacy is less important for their choices compared with the accrued effects of expe- 
rience and learning.

\subsubsection{Time Lag After Refinancing}

The relationship between financial literacy and mortgage choices may also be sensitive to the length of time since mortgage refinancing. In Table A5 we show estimates by subsamples of recent refinancers (within the past 3 years) and earlier refinancers. Results show the relationship between financial literacy and the likelihood of holding an AMP is stronger and statistically more significant for the sub-sample of recent mortgage refinancers (Column 1) compared with earlier refinancers (Column 2), with a Chow test confirming the coefficients in the two columns in the financial literacy index are statistically significantly different from one another $(\mathrm{p}=0.000)$. Results for interest rate type indicator a slightly stronger relationship for households who refinanced recently, but the Chow test result cannot reject the null of equivalence $(\mathrm{p}=0.758)$.

We also find a positive and statistically significant coefficient on the credit constrained dummy variable for recently refinanced households, with the marginal effect implying that a household that is credit constrained is more than twice as likely to choose an AMP. This implies that credit constraints are important for the mortgage commitments taken on by households, with credit constrained households being less likely to choose SMPs with higher up-front payments. We further investigate interactions between financial literacy and credit constraints in Table A6. Here we find a positive coefficient on the interaction, implying that credit constraints raise the likelihood of holding an AMP among households with higher financial literacy. This indicates that, faced with credit constraints, more financially literate households may realize that to purchase a (large) home, they can only do so with an AMP with its lower initial payments.

\subsubsection{Sensitivity to Mortgage Classification}

In addition to the above tests, we also examine the sensitivity of our IV probit results for mortgage repayment type to the definition of 'AMP' and the treatment of 'don't know' answers. First, we consider the definition of an AMP classification. We re-estimate the IV probit model excluding individuals with endowment-linked $\mathrm{AMPs}^{20}$. This removes 36

\footnotetext{
${ }^{20}$ As described in Section 2, some AMP mortgages were historically sold with linked equity investment vehicles. Importantly, the endowment provider does not guarantee any shortfall in the value of these equity investments at the maturity of the mortgage, so an endowment-linked AMP does not guarantee principal repayment. However, an endowment-linked AMP could be considered to be a partial repayment mortgage. Therefore, to examine the robustness of our estimates to possible mis-classification of these mortgages.
} 
observations from our estimation sample (24\% of those previously defined as AMPs). Results are shown in Table A7 in Column 1. Our estimates are very similar to before. Financial literacy remains negative and statistically significant at the $1 \%$ level and the marginal effect on the literacy score increases in absolute value a little. The implied effects of a one unit increase in literacy on the likelihood of holding an AMP is a $70 \%$ decrease. The dummy variable for present biased individuals is significant at the $1 \%$ level and the marginal effect is near identical.

Second, we consider treatment of 'don't know' answers to our mortgage financial literacy questions ${ }^{21}$. In Column 2 we exclude individuals who might be of the latter type from the estimation sample. We remove observations with 'don't' know' responses to the first financial literacy question (which is the easiest question). We also remove observations with three or more 'don't know' answers. This excludes 68 individuals from our sample. When we do so, model estimates are again very similar to before, with very similar coefficient and marginal effect magnitudes for financial literacy and behavioral characteristics. In Column 4 we estimate the interest rate type model excluding 'don't know' responses with the same criteria. Our results are nearly unchanged by the omission, and financial literacy remains positive and statistically significant at the $1 \%$ level.

Third, in Column 3, we estimate a model which excludes individuals who are excluded by the sample selections in Columns 1 and 2 (102 observations). Again, the coefficient estimates and marginal effects are very similar.

\subsubsection{Financial Literacy and Time Preferences}

Finally, we explore interaction effects between financial literacy and present bias. We first estimate models in which the financial literacy score is interacted with the present bias indicator variable. Theory suggests (see, for example, O'Donoghue and Rabin, 1999) that individuals who are present biased yet sophisticated will prefer to commit to repayment. Results from models with interaction effects are presented in Table A8 and indicate no statistically significant interaction effect between these variables. Importantly, financial literacy remains positive and statistically significant.

In further results not shown we also estimate a series of models where we include

\footnotetext{
${ }^{21}$ One potential problem with responses to our questions is that some individuals might answer 'don't know' simply to avoid the (cognitive) effort involved in answering the questions. Hence 'don' $t$ ' know' responses will comprise some genuine answers on the part of the respondents plus some answers stated simply to avoid exerting effort in attempting an answer.
} 
financial literacy, present bias and patience individually and in all combinations. We estimate these models as non-instrumented probit models, similar Columns 2 and 4 in Table A2, as IV and non-IV models are not directly comparable. When we do this, we find that the pattern of statistical significance, magnitude of coefficients and marginal effects are very close to those of our main results in Tables 6 and 7 (Columns 3 and 4). For the repayment type models, financial literacy remains highly significant and negative, present bias is positive and significant, and patience remains statistically not significant. For the interest type models, as before, only financial literacy is positive and significant.

\section{Conclusion}

In this paper, we estimate the impact of financial literacy and behavioral traits on mortgage choices. We consider the choice between standard and alternative mortgage products and also the choice between adjustable and fixed rate mortgages. Our results are obtained using an instrumental variable (IV) strategy which addresses the potential endogeneity of financial literacy to mortgage market experience.

Our analysis highlights several key results: We show financial literacy is, on average, poor among those holding alternative mortgage products. Econometric results show that these differences in financial literacy among mortgagees give rise to large and statistically significant effects on the choice of AMP vs SMP in multivariate regression models. Results show a one-point increase in financial literacy lowers the likelihood of an individual holding an AMP by 53\%. Our results are in contrast to studies using Dutch mortgage data, where alternative mortgages have different features, which find a positive relation between financial literacy and AMP holding (van Ooijen and van Rooij, 2016; Cox et al., 2015). However, van Ooijen and van Rooij (2016) find that among households who take out mortgages via mortgage brokers, those who are less financially literate choose riskier mortgages such as AMP mortgages (with a linked investment vehicle) or high loan-to-value ratio ARM mortgages. This is consistent with our findings.

We also show that financial literacy is related to the choice of the type of interest rate of a mortgage. Econometric estimates show that a unit increase in literacy increases the likelihood of holding an ARM by $22 \%$. This suggests that consumers with higher financial literacy are more likely to appreciate the term premium cost of a fixed rate mortgage. Results also reveal that there is no evidence that present bias or patience are important for the interest rate type decision. 
Further results show that present bias is an important predictor for the choice of an AMP. Holders of AMPs are much more likely to be present biased (20\% among AMP holders compared with 10\% among SMP holders). Our econometric estimates show that this difference gives rise to large and statistically significant effects on the choice of AMP vs SMP, but not in the choice of ARM vs. FRM. Being present biased increases the likelihood of an individual holding an AMP by around $50 \%$. At the same time, patience is not significantly related to the choice of holding an AMP. In contrast to these results, neither patience nor present bias are significantly related to the interest rate type choice of a mortgage.

We also find some heterogeneity in the relationship between financial literacy, present bias and mortgage choices across households by age and income. Financial literacy is more important for mortgage choices among younger households. Present bias is only relevant for low income households, though the effect is not statistically significantly different to that for high income households.

In additional analysis, we show further mechanisms at work in mortgage choices: mortgage repayment and interest rate types are sensitive to local house price dynamics and also responsive to the term premium. We show evidence that financially literate households respond in their mortgage interest rate type choices to the term premium, but those with poor financial literacy do not.

How should we interpret our results for the relationship between financial literacy, present bias and mortgage choice? We interpret this as evidence that behavioral characteristics are important for mortgage choices. For some consumers, the choice of an AMP may be the result of misunderstanding features of the mortgage product and our results are suggestive (without proving) that this is the case. They also suggest that myopic consumers who put little weight on the future are more prone to choosing an AMP. Although our data does not allow judgment whether a mortgage choice was ex-ante optimal for a household, results show AMP mortgages attract some customers who lack financial sophistication and may, as a result, make mistakes in their mortgage choices. 


\section{References}

Ameriks, J., Caplin, A., Leahy, J., and Tyler, T. (2007). Measuring Self-Control Problems. American Economic Review, 97(3), 966-972.

Badarinza, C., Campbell, J., and Ramadorai, T. (2016). What Calls to ARMs? International Evidence on Interest Rates and the Choice of Adjustable-Rate Mortgages. Management Science, (forthcoming).

Bernanke, B. (2010). Monetary policy and the housing bubble: Speech at the Annual Meeting of the American Economic Association. Speech from Board of Governors of the Federal Reserve System, 499.

Burks, S., Carpenter, J., Götte, L., and Rustichini, A. (2012). Which measures of time preference best predict outcomes: Evidence from a large-scale field experiment. Journal of Economic Behavior \& Organization, 84(1), 308-320.

Busse, M.R., Knittel, C.R., and Zettelmeyer, F. (2013). Are Consumers Myopic? Evidence from New and Used Car Purchases. American Economic Review, 103(1), 220-256.

Campbell, J.Y. and Cocco, J.F. (2003). Household Risk Management and Optimal Mortgage Choice. Quarterly Journal of Economics, 118(4), 1449-1494.

Cocco, J.F. (2013). Evidence on the benefits of alternative mortgage products. Journal of Finance, 68(4), 1663-1690.

Cox, R., Brounen, D., and Neuteboom, P. (2015). Financial Literacy, Risk Aversion and Choice of Mortgage Type by Households. The Journal of Real Estate Finance and Economics, 50(1), 74-112.

DellaVigna, S. and Malmendier, U. (2004). Contract Design and Self-Control: Theory and Evidence. The Quarterly Journal of Economics, 119(2), 353-402.

Disney, R. and Gathergood, J. (2013). Financial literacy and consumer credit portfolios. Journal of Banking \& Finance, 37(7), 2246-2254.

Dohmen, T., Falk, A., Huffman, D., and Sunde, U. (2010). Are Risk Aversion and Impatience Related to Cognitive Ability? American Economic Review, 100(3), 1238-1260.

Dohmen, T., Falk, A., Huffman, D., Sunde, U., Schupp, J., and Wagner, G.G. (2011). Individual Risk Attitudes: Measurement, Determinants, and Behavioral Consequences. Journal of the European Economic Association, 9(3), 522-550. 
Duca, J. V. and Kumar, A. (2014). Financial literacy and mortgage equity withdrawals. Journal of Urban Economics, 80, 62-75.

Einav, L., Jenkins, M., and Levin, J. (2012). Contract Pricing in Consumer Credit Markets. Econometrica, 80(4), 1387-1432.

Financial Conduct Authority. (2013). Dealing fairly with interest-only mortgage customers who risk being unable to repay their loan. FCA Guidance Reports, FG13/7.

Gathergood, J. (2012). Self-control, financial literacy and consumer overindebtedness. Journal of Economic Psychology, 33(3), 590-602.

Gathergood, J. and Weber, J. (2014). Self-Control, Financial Literacy \& the Co-Holding Puzzle. Journal of Economic Behavior \& Organization, 107(Part B), 455-469.

Gerardi, K., Goette, L., and Meier, S. (2013). Numerical ability predicts mortgage default. Proceedings of the National Academy of Sciences of the United States of America, 110(28), 11267-71.

Ghent, A. (2015). Home Ownership, Household Leverage and Hyperbolic Discounting. Real Estate Economics, 43(3), 750-781.

Guiso, L. and Jappelli, T. (2005). Awareness and Stock Market Participation. Review of Finance, 9(4), 537-567.

Gul, F. and Pesendorfer, W. (2001). Temptation and Self-Control. Econometrica, 69(6), $1403-1435$.

Heidhues, P. and Köszegi, B. (2010). Exploiting Naïvete about Self-Control in the Credit Market. American Economic Review, 100(5), 2279-2303.

Jappelli, T. and Padula, M. (2013). Investment in financial literacy and saving decisions. Journal of Banking \& Finance, 37(8), 2779-2792.

Koijen, R.S.J., Hemert, O. Van, and Nieuwerburgh, S. Van. (2009). Mortgage timing. Journal of Financial Economics, 93(2), 292-324.

LaCour-Little, M. and Yang, J. (2010). Pay Me Now or Pay Me Later: Alternative Mortgage Products and the Mortgage Crisis. Real Estate Economics, 38(4), 687-732.

Laibson, D. (1997). Golden Eggs and Hyperbolic Discounting. The Quarterly Journal of Economics, 112(2), 443-478.

Laibson, D., Repetto, A., and Tobacman, J. (2003). A Debt Puzzle. In P. Aghion, R. Frydman, 
J. Stiglitz, \& M. Woodford (Eds.), Knowledge, Information, and Expectations in Modern Economics: In Honor of Edmund S. Phelps (pp. 228-266). Princeton: Pinceton University Press.

Lusardi, A. and Mitchell, O.S. (2007a). Baby Boomer retirement security: The roles of planning, financial literacy, and housing wealth. Journal of Monetary Economics, 54(1), $205-224$.

Lusardi, A. and Mitchell, O.S. (2007b). Financial Literacy and Retirement Preparedness: Evidence and Implications for Financial Education. Business Economics, 42(1), 35-44.

Lusardi, A. and Mitchell, O.S. (2014). The Economic Importance of Financial Literacy: Theory and Evidence. Journal of Economic Literature, 52(1), 5-44.

Lusardi, A. and Tufano, P. (2015). Debt literacy, financial experiences, and overindebtedness. Journal of Pension Economics and Finance, 14(4), 332-368.

Malik, S. and Meldrum, A. (2016). Evaluating the robustness of UK term structure decompositions using linear regression methods. Journal of Banking and Finance, 67, $85-102$.

Mayer, C., Pence, K., and Sherlund, S.M. (2009). The Rise in Mortgage Defaults. Journal of Economic Perspectives, 23(1), 27-50.

Meier, S. and Sprenger, C. (2010). Present-Biased Preferences and Credit Card Borrowing. American Economic Journal: Applied Economics, 2(1), 193-210.

Meier, S. and Sprenger, C.D. (2013). Discounting financial literacy: Time preferences and participation in financial education programs. Journal of Economic Behavior \& Organization, 95, 159-174.

Miles, D. (2004). The UK Mortgage Market: Taking a Longer-Term View - Final Report and Recommendations. London: Her Majesty’s Stationery Office.

O’Donoghue, T. and Rabin, M. (1999). Doing It Now or Later. The American Economic Review, 89(1), 103-124.

Piskorski, T. and Tchistyi, A. (2010). Optimal Mortgage Design. The Review of Financial Studies, 23(8), 3098-3140.

Stanton, R. and Wallace, N. (1999). Anatomy of an ARM: The interest-rate risk of adjustablerate mortgages. The Journal of Real Estate Finance and Economics, 19(1), 49-67. 
Stock, J. and Yogo, M. (2005). Testing for Weak Instruments in Linear IV Regression. Identification and Inference for Econometric Models.

Strotz, R.H. (1955). Myopia and Inconsistency in Dynamic Utility Maximization. The Review of Economic Studies, 23(3), 165-180.

Thaler, R.H. and Shefrin, H.M. (1981). An Economic Theory of Self-Control. Journal of Political Economy, 89(2), 392-406.

van Ooijen, R. and van Rooij, M.C.J. (2016). Mortgage risks, debt literacy and financial advice. Journal of Banking \& Finance, 72(449), 201-217.

van Rooij, M., Lusardi, A., and Alessie, R.J.M. (2011a). Financial literacy and retirement planning in the Netherlands. Journal of Economic Psychology, 32(4), 593-608.

van Rooij, M., Lusardi, A., and Alessie, R.J.M. (2011b). Financial literacy and stock market participation. Journal of Financial Economics, 101(2), 449-472.

Vischer, T., Dohmen, T., Falk, A., Huffman, D., Schupp, J., Sunde, U., and Wagner, G.G. (2013). Validating an ultra-short survey measure of patience. Economics Letters, 120(2), $142-145$. 
Table 1: Sample Characteristics

\begin{tabular}{|c|c|c|c|c|}
\hline & $\begin{array}{c}(1) \\
\text { Full } \\
\text { Sample }\end{array}$ & $\begin{array}{c}(2) \\
\text { Mortgage } \\
\text { Holder }\end{array}$ & $\begin{array}{c}(3) \\
\text { Outright } \\
\text { Homeowner }\end{array}$ & $\begin{array}{c}(4) \\
\text { Renter }\end{array}$ \\
\hline \multicolumn{5}{|l|}{ Age } \\
\hline $18-34$ & 0.23 & 0.22 & 0.02 & 0.43 \\
\hline $35-44$ & 0.18 & 0.30 & 0.05 & 0.19 \\
\hline $45-54$ & 0.18 & 0.27 & 0.13 & 0.15 \\
\hline $55+$ & 0.41 & 0.21 & 0.79 & 0.23 \\
\hline \multicolumn{5}{|l|}{ Demographics } \\
\hline Male (= 1) & 0.50 & 0.53 & 0.53 & 0.46 \\
\hline Married/living as married $(=1)$ & 0.64 & 0.77 & 0.78 & 0.40 \\
\hline Dependent children $(=1)$ & 0.20 & 0.36 & 0.05 & 0.19 \\
\hline Education leaving age & 18.44 & 18.95 & 17.74 & 18.63 \\
\hline Math level in school (1-5) & 3.59 & 3.69 & 3.54 & 3.53 \\
\hline \multicolumn{5}{|l|}{ Employment } \\
\hline Employed (= 1) & 0.59 & 0.85 & 0.31 & 0.60 \\
\hline Unemployed (= 1) & 0.02 & 0.01 & 0.01 & 0.05 \\
\hline Retired/Student/Housewife/Disabled & 0.39 & 0.14 & 0.69 & 0.35 \\
\hline Spouse employed (= 1) & 0.37 & 0.62 & 0.26 & 0.24 \\
\hline \multicolumn{5}{|l|}{ Household Finances } \\
\hline Recent income loss $(=1)$ & 0.13 & 0.14 & 0.09 & 0.16 \\
\hline Credit constrained $(=1)$ & 0.07 & 0.06 & 0.03 & 0.12 \\
\hline Household income (£) & $\begin{array}{c}32900 \\
(28000)\end{array}$ & $\begin{array}{c}43600 \\
(39000)\end{array}$ & $\begin{array}{l}29400 \\
(24400)\end{array}$ & $\begin{array}{l}26400 \\
(23000)\end{array}$ \\
\hline Observations & 1974 & 632 & 634 & 708 \\
\hline
\end{tabular}

Note: Table shows summary statistics for all individuals in the survey (Column 1), plus for all individuals divided into three mutually exclusive and exhaustive groups: those owning a home via a mortgage (Column 2), those who are outright home owners i.e. with no mortgage (Column 3), and those renting (Column 4). The variable 'education leaving age' is the age at which the individual finished full-time education. The variable 'math level in school' is the individual's self-reported mathematical ability at school on a scale from 1 to 5 . Mean values reported, medians in parentheses for financial variables. 
Table 2: Demographic and Housing Characteristics of Mortgage Holders

\begin{tabular}{|c|c|c|c|c|c|}
\hline & \multirow{2}{*}{$\begin{array}{c}\text { (1) } \\
\text { All Mortgage } \\
\text { Holders }\end{array}$} & \multicolumn{2}{|c|}{ (2) Repayment Type } & \multicolumn{2}{|c|}{ (3) Interest Rate Type } \\
\hline & & $\begin{array}{l}\text { Standard } \\
\text { Mortgage } \\
\text { (SMP) }\end{array}$ & $\begin{array}{c}\text { Alternative } \\
\text { Mortgage } \\
\text { (AMP) }\end{array}$ & $\begin{array}{l}\text { Fixed } \\
\text { Rate } \\
(\mathrm{FRM})\end{array}$ & $\begin{array}{c}\text { Adjustable } \\
\text { Rate } \\
\text { (ARM) }\end{array}$ \\
\hline \multicolumn{6}{|l|}{ Age } \\
\hline $18-34$ & 0.22 & 0.24 & 0.14 & 0.27 & 0.17 \\
\hline $35-44$ & 0.30 & 0.32 & 0.23 & 0.28 & 0.32 \\
\hline $45-54$ & 0.27 & 0.28 & 0.25 & 0.28 & 0.26 \\
\hline $55+$ & 0.21 & 0.16 & 0.39 & 0.17 & 0.25 \\
\hline \multicolumn{6}{|l|}{ Demographics } \\
\hline Male $(=1)$ & 0.53 & 0.54 & 0.46 & 0.48 & 0.57 \\
\hline Married/living as married $(=1)$ & 0.77 & 0.77 & 0.76 & 0.73 & 0.80 \\
\hline Dependent children $(=1)$ & 0.36 & 0.37 & 0.32 & 0.33 & 0.39 \\
\hline Education leaving age & 18.95 & 19.15 & 18.23 & 19.19 & 18.74 \\
\hline Math level in school (1-5) & 3.69 & 3.75 & 3.49 & 3.60 & 3.77 \\
\hline \multicolumn{6}{|l|}{ Employment } \\
\hline Employed (= 1) & 0.85 & 0.89 & 0.73 & 0.88 & 0.83 \\
\hline Unemployed $(=1)$ & 0.01 & 0.01 & 0.01 & 0.00 & 0.01 \\
\hline Retired/Student/Housewife/Disabled & 0.14 & 0.11 & 0.26 & 0.12 & 0.16 \\
\hline Spouse employed $(=1)$ & 0.62 & 0.64 & 0.54 & 0.64 & 0.59 \\
\hline \multicolumn{6}{|l|}{ Household Finances } \\
\hline Recent income loss $(=1)$ & 0.14 & 0.13 & 0.18 & 0.11 & 0.17 \\
\hline Credit constrained $(=1)$ & 0.06 & 0.05 & 0.08 & 0.05 & 0.06 \\
\hline Household income $(\mathfrak{f})$ & $\begin{array}{c}43600 \\
(39000)\end{array}$ & $\begin{array}{c}44400 \\
(40000)\end{array}$ & $\begin{array}{c}40700 \\
(34000)\end{array}$ & $\begin{array}{c}44000 \\
(40000)\end{array}$ & $\begin{array}{c}43200 \\
(38000)\end{array}$ \\
\hline \multicolumn{6}{|l|}{ Housing } \\
\hline Property value $(\mathfrak{f})$ & $\begin{array}{c}204900 \\
(170000)\end{array}$ & $\begin{array}{c}202600 \\
(165000)\end{array}$ & $\begin{array}{c}212800 \\
(177500)\end{array}$ & $\begin{array}{c}204100 \\
(172500)\end{array}$ & $\begin{array}{c}205600 \\
(165000)\end{array}$ \\
\hline Mortgage outstanding amount $(£)$ & $\begin{array}{c}91700 \\
(80000)\end{array}$ & $\begin{array}{c}91500 \\
(80000)\end{array}$ & $\begin{array}{c}92500 \\
(77900)\end{array}$ & $\begin{array}{c}95600 \\
(82000)\end{array}$ & $\begin{array}{c}88300 \\
(77000)\end{array}$ \\
\hline Adjustable rate mortgage (ARM) & 0.53 & 0.50 & 0.67 & 0.00 & 1.00 \\
\hline Mortgage interest rate & 3.54 & 3.59 & 3.37 & 4.00 & 3.14 \\
\hline Loan-to-income ratio & 2.41 & 2.35 & 2.61 & 2.48 & 2.34 \\
\hline Loan-to-value ratio & 0.55 & 0.56 & 0.52 & 0.53 & 0.57 \\
\hline Term premium (in \%) & 0.46 & 0.47 & 0.41 & 0.60 & 0.33 \\
\hline Observations & 632 & 492 & 140 & 294 & 338 \\
\hline
\end{tabular}

Note: Column 1 shows summary statistics for the 632 mortgage holders in the sample. Column 2 divides the sample by mortgage repayment type, Column 3 divides the sample by mortgage interest rate type. A 'Standard Mortgage' (SMP) is a capital repayment mortgage in which mortgage payments include payment of the principal which declines to zero over the term of the mortgage. An 'Alternative Mortgage' (AMP) is a mortgage in which mortgage payments meet the interest on the principal. A 'Fixed Rate Mortgage' (FRM) is a mortgage in which the nominal interest rate is fixed for some or all of the mortgage term. An 'Adjustable Rate Mortgage' (ARM) is a mortgage for which the interest rate varies over the mortgage term, in the majority of cases the interest rate is linked to the Bank of England repo rate.

Mean values reported, medians in parentheses for financial variables. 
Table 3: Mortgage Financial Literacy Performance

$(1)$

All $\begin{gathered}\text { Standard } \\ \text { Mortgage } \\ \text { (SMP) }\end{gathered} \quad \begin{gathered}\text { Alternative } \\ \text { Mortgage } \\ \text { (AMP) }\end{gathered} \quad p$-value

(3) Interest Rate Type

$\begin{array}{ccc}\text { Fixed } & \text { Adjustable } & \\ \text { Rate } & \text { Rate } & \text {-value } \\ \text { (FRM) } & \text { (ARM) } & \end{array}$

1. Suppose a 15 year mortgage and a 30 year mortgage have the same Annual Percentage Rate and the same amount borrowed. The total amount repaid will be:

Higher for the 15 year mortgage

Higher for the 30 year mortgage

$\begin{array}{ll}0.05 & 0.03 \\ 0.81 & 0.87 \\ 0.08 & 0.05 \\ 0.07 & 0.05\end{array}$

$\begin{array}{lll}0.11 & 0.000 & 0.07 \\ 0.59 & 0.000 & 0.78 \\ 0.18 & 0.000 & 0.08 \\ 0.12 & 0.004 & 0.08\end{array}$

0.04
0.83
0.07
0.06

0.091

The total amount repaid will be the same

Don't know

0.07

0.05

0.12

0.004

0.08

0.06

0.077

0.720

0.343

2. Suppose you owe $£ 50,000$ on a mortgage at an Annual Percentage Rate of $6 \%$. If you didn’t make any payments on this mortgage how much would you owe in total after one year?

$\begin{array}{llllllll}\text { Less than } £ 50,000 & 0.03 & 0.02 & 0.06 & 0.002 & 0.02 & 0.04 & 0.152 \\ £ 50,000-£ 54,999 & 0.66 & 0.72 & 0.44 & 0.000 & 0.64 & 0.67 & 0.349 \\ £ 55,000-£ 59,999 & 0.14 & 0.12 & 0.19 & 0.032 & 0.14 & 0.14 & 0.913 \\ £ 60,000-£ 64,999 & 0.03 & 0.02 & 0.06 & 0.007 & 0.03 & 0.02 & 0.430 \\ \text { More than } £ 65,000 & 0.05 & 0.05 & 0.07 & 0.295 & 0.06 & 0.05 & 0.441 \\ \text { Don't know } & 0.10 & 0.08 & 0.17 & 0.002 & 0.12 & 0.09 & 0.167\end{array}$

3. Suppose you owe $£ 100,000$ on a mortgage at an Annual Percentage Rate of 5\%. If you didn’t make any payments on this mortgage how much would you owe in total after five years?

$\begin{array}{llllllll}\text { Less than } £ 120,000 & 0.15 & 0.14 & 0.17 & 0.359 & 0.13 & 0.16 & 0.338 \\ \text { Between } £ 120,000 \text { and } £ 125,000 & 0.24 & 0.21 & 0.35 & 0.000 & 0.26 & 0.22 & 0.282 \\ \text { More than } 1125,000 & 0.51 & 0.58 & 0.28 & 0.000 & 0.49 & 0.53 & 0.284 \\ \text { Don’t know } & 0.10 & 0.07 & 0.20 & 0.000 & 0.12 & 0.09 & 0.167\end{array}$

4. Suppose you owe $£ 200,000$ on a mortgage with at an Annual Percentage Rate of $5 \%$. If you made annual payments of $£ 10,000$ per year how long would it take to repay the whole mortgage?

\begin{tabular}{lccccccc} 
Less than 20 years & 0.03 & 0.02 & 0.07 & 0.001 & 0.03 & 0.02 & 0.436 \\
Between 20 and 30 years & 0.30 & 0.30 & 0.29 & 0.731 & 0.29 & 0.30 & 0.800 \\
Between 30 and 40 years & 0.12 & 0.11 & 0.16 & 0.148 & 0.11 & 0.13 & 0.493 \\
The mortgage would never be repaid & 0.37 & 0.41 & 0.26 & 0.001 & 0.33 & 0.41 & 0.035 \\
Don't know & 0.18 & 0.17 & 0.23 & 0.082 & 0.23 & 0.13 & 0.001 \\
\hline Literacy score (0-4) & 2.35 & 2.57 & 1.56 & 0.000 & 2.23 & 2.45 & 0.030 \\
\hline Observations & 632 & 492 & 140 & 632 & 294 & 338 & 632 \\
\hline
\end{tabular}

Note: Table shows breakdown of answers to financial literacy questions. Column 1 shows statistics for all mortgage holders. Columns 2 and 3 show statistics for mortgage holders by their mortgage repayment type and mortgage interest rate type. $p$-values of t-tests are reported from comparing households by mortgage repayment type and interest rate type. 
Table 4: Characteristics of Mortgage Holders by Mortgage Literacy

\begin{tabular}{|c|c|c|c|c|c|}
\hline & 0 & 1 & 2 & 3 & 4 \\
\hline \multicolumn{6}{|l|}{ Age } \\
\hline $18-34$ & 0.33 & 0.19 & 0.21 & 0.18 & 0.24 \\
\hline $35-44$ & 0.21 & 0.27 & 0.30 & 0.29 & 0.36 \\
\hline $45-54$ & 0.32 & 0.27 & 0.26 & 0.31 & 0.23 \\
\hline $55+$ & 0.14 & 0.28 & 0.23 & 0.22 & 0.17 \\
\hline \multicolumn{6}{|l|}{ Demographics } \\
\hline Male $(=1)$ & 0.27 & 0.48 & 0.48 & 0.58 & 0.67 \\
\hline Married/living as married $(=1)$ & 0.78 & 0.73 & 0.72 & 0.77 & 0.83 \\
\hline Dependent children $(=1)$ & 0.33 & 0.33 & 0.33 & 0.37 & 0.42 \\
\hline Education leaving age & 18.42 & 18.18 & 18.73 & 19.38 & 19.47 \\
\hline Math level in school (1-5) & 2.92 & 3.37 & 3.68 & 3.93 & 3.99 \\
\hline \multicolumn{6}{|l|}{ Employment } \\
\hline Employed (= 1) & 0.79 & 0.85 & 0.85 & 0.88 & 0.85 \\
\hline Unemployed $(=1)$ & 0.00 & 0.00 & 0.02 & 0.00 & 0.01 \\
\hline Retired/Student/Housewife/Disabled & 0.21 & 0.15 & 0.13 & 0.12 & 0.14 \\
\hline Spouse employed $(=1)$ & 0.71 & 0.59 & 0.61 & 0.66 & 0.54 \\
\hline \multicolumn{6}{|l|}{ Household Finances } \\
\hline Household income $(\mathfrak{E})$ & $\begin{array}{c}37400 \\
(33000)\end{array}$ & $\begin{array}{c}38400 \\
(35000)\end{array}$ & $\begin{array}{c}41500 \\
(36500)\end{array}$ & $\begin{array}{c}47600 \\
(45000)\end{array}$ & $\begin{array}{c}47800 \\
(40100)\end{array}$ \\
\hline \multicolumn{6}{|l|}{ Housing } \\
\hline Property value $(\mathfrak{E})$ & $\begin{array}{c}167800 \\
(153000)\end{array}$ & $\begin{array}{c}188600 \\
(158400)\end{array}$ & $\begin{array}{c}198900 \\
(160000)\end{array}$ & $\begin{array}{c}214700 \\
(180000)\end{array}$ & $\begin{array}{c}228800 \\
(180000)\end{array}$ \\
\hline Mortgage outstanding amount $(£)$ & $\begin{array}{c}82300 \\
(75000)\end{array}$ & $\begin{array}{c}89900 \\
(74800)\end{array}$ & $\begin{array}{c}91600 \\
(81500)\end{array}$ & $\begin{array}{c}86900 \\
(80000)\end{array}$ & $\begin{array}{l}103100 \\
(97000)\end{array}$ \\
\hline Mortgage interest rate & 3.60 & 3.95 & 3.38 & 3.37 & 3.63 \\
\hline Loan-to-income ratio & 2.32 & 2.89 & 2.37 & 2.08 & 2.54 \\
\hline Loan-to-value ratio & 0.55 & 0.58 & 0.53 & 0.46 & 0.66 \\
\hline Alternative mortgage product (AMP) & 0.67 & 0.32 & 0.18 & 0.13 & 0.12 \\
\hline Adjustable rate mortgage (ARM) & 0.44 & 0.51 & 0.52 & 0.53 & 0.61 \\
\hline Term premium (in \%) & 0.45 & 0.46 & 0.45 & 0.48 & 0.43 \\
\hline \multicolumn{6}{|l|}{ Behavioral Characteristics } \\
\hline Present biased $(=1)$ & 0.19 & 0.17 & 0.14 & 0.07 & 0.12 \\
\hline Patience $(0-10)$ & 5.51 & 6.21 & 5.67 & 5.74 & 4.78 \\
\hline Risk attitude (0-10) & 4.05 & 4.71 & 4.29 & 4.42 & 3.99 \\
\hline Observations & 63 & 94 & 174 & 163 & 138 \\
\hline
\end{tabular}

Note: Table shows summary statistics for mortgage holders by their financial literacy score (number of financial literacy questions answered correctly). Mean values reported, medians in parentheses for financial variables. 
Table 5: Behavioral Characteristics

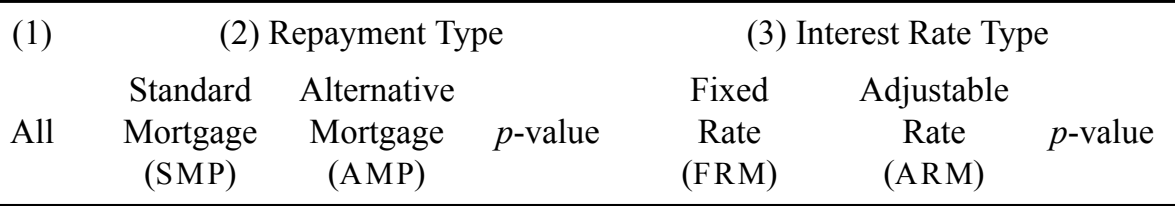

Patience: "Are you generally an impatient person, or someone who always shows great patience?

Answers are coded on an 11-point scale, with ' 0 ' referring to 'very impatient' and ' 10 ' to 'very patient'."

\begin{tabular}{|c|c|c|c|c|c|c|c|}
\hline Patience $(0-10)$ & $\begin{array}{c}5.56 \\
(6.00) \\
{[2.55]}\end{array}$ & $\begin{array}{c}5.48 \\
(6.00) \\
{[2.56]}\end{array}$ & $\begin{array}{c}5.83 \\
(6.00) \\
{[2.52]}\end{array}$ & 0.158 & $\begin{array}{c}5.71 \\
(6.00) \\
{[2.40]}\end{array}$ & $\begin{array}{c}5.43 \\
(5.00) \\
{[2.67]}\end{array}$ & 0.176 \\
\hline Agree strongly & 0.02 & 0.01 & 0.05 & 0.005 & 0.01 & 0.03 & 0.087 \\
\hline Tend to agree & 0.11 & 0.10 & 0.14 & 0.127 & 0.12 & 0.10 & 0.543 \\
\hline Neither agree nor disagree & 0.20 & 0.20 & 0.20 & 0.975 & 0.18 & 0.22 & 0.159 \\
\hline Tend to disagree & 0.32 & 0.33 & 0.27 & 0.180 & 0.36 & 0.28 & 0.032 \\
\hline Disagree strongly & 0.34 & 0.34 & 0.31 & 0.520 & 0.32 & 0.35 & 0.491 \\
\hline Don’t know & 0.02 & 0.01 & 0.02 & 0.548 & 0.01 & 0.02 & 0.678 \\
\hline Present biased $(=1)^{\mathrm{a}}$ & 0.13 & 0.11 & 0.19 & 0.009 & 0.13 & 0.13 & 0.871 \\
\hline
\end{tabular}

Risk attitude (self-assessed): "Are you generally a person who is fully prepared to take risks or do you try to avoid taking risks? Answers are coded on an 11-point scale, with 0 referring to 'unwilling to take risks' and 10 'fully prepared to take risk'."

\begin{tabular}{|c|c|c|c|c|c|c|c|}
\hline Risk attitude $(0-10)$ & $\begin{array}{c}4.30 \\
(4.00) \\
{[2.17]}\end{array}$ & $\begin{array}{c}4.39 \\
(4.00) \\
{[2.18]}\end{array}$ & $\begin{array}{c}3.99 \\
(4.00) \\
{[2.09]}\end{array}$ & 0.054 & $\begin{array}{c}4.51 \\
(4.50) \\
{[2.06]}\end{array}$ & $\begin{array}{c}4.11 \\
(4.00) \\
{[2.25]}\end{array}$ & 0.019 \\
\hline Observations & 632 & 492 & 140 & 632 & 294 & 338 & 632 \\
\hline
\end{tabular}

a 'Present biased' = 1 if answer 'agree strongly' or 'tend to agree', and $=0$ otherwise.

Note: Table shows breakdown of answers to behavioral characteristics questions. Column 1 shows statistics for all mortgage holders. Columns 2 and 3 show statistics for mortgage holders by their mortgage repayment type and mortgage interest rate type. Mean values reported, medians in parentheses and standard deviations in square brackets. $p$-values of t-tests are reported from comparing households by mortgage repayment type and interest rate type 
Table 6: Repayment Type Models

\begin{tabular}{|c|c|c|c|c|c|c|c|c|}
\hline & \multicolumn{2}{|c|}{$\begin{array}{c}(1) \\
\text { Baseline } \\
\text { Repayment Type } \\
(\mathrm{AMP}=1)\end{array}$} & \multicolumn{2}{|c|}{$\begin{array}{c}(2) \\
+ \text { Behavioral } \\
\text { Repayment Type } \\
(\text { AMP }=1)\end{array}$} & \multicolumn{2}{|c|}{$\begin{array}{c}(3) \\
+ \text { Housing } \\
\text { Repayment Type } \\
(\mathrm{AMP}=1)\end{array}$} & \multicolumn{2}{|c|}{$\begin{array}{c}(4) \\
\text { Complete } \\
\text { Repayment Type } \\
(\mathrm{AMP}=1)\end{array}$} \\
\hline \multicolumn{9}{|l|}{ Financial Literacy } \\
\hline Literacy score $(0-4)$ & $\begin{array}{c}-0.454 * * * \\
(0.156)\end{array}$ & $-0.107 * * *$ & $\begin{array}{c}-0.428 * * * \\
(0.158)\end{array}$ & $-0.098 * * *$ & $\begin{array}{c}-0.609 * * * \\
(0.158)\end{array}$ & $-0.128^{* * *}$ & $\begin{array}{c}-0.578^{* * * *} \\
(0.161)\end{array}$ & $-0.120 * * *$ \\
\hline Present biased $(=1)$ & & & $\begin{array}{l}0.570 * * * \\
(0.182)\end{array}$ & $0.131 * * *$ & & & $\begin{array}{l}0.491 * * \\
(0.193)\end{array}$ & $0.102 * *$ \\
\hline Patience $(0-10)$ & & & $\begin{array}{c}0.008 \\
(0.027)\end{array}$ & 0.002 & & & $\begin{array}{c}0.004 \\
(0.028)\end{array}$ & 0.001 \\
\hline Risk attitude $(0-10)$ & & & $\begin{array}{c}-0.079 * * \\
(0.032)\end{array}$ & $-0.018^{* *}$ & & & $\begin{array}{c}-0.069^{* *} \\
(0.034)\end{array}$ & $-0.014^{* *}$ \\
\hline Loan-to-value ratio & & & & & $\begin{array}{c}-0.167 \\
(0.209)\end{array}$ & -0.035 & $\begin{array}{c}-0.170 \\
(0.210)\end{array}$ & -0.035 \\
\hline Loan-to-income ratio & & & & & $\begin{array}{c}-0.017 \\
(0.062)\end{array}$ & -0.004 & $\begin{array}{c}-0.021 \\
(0.063)\end{array}$ & -0.004 \\
\hline Mortgage interest rate & & & & & $\begin{array}{c}-0.008 \\
(0.023)\end{array}$ & -0.002 & $\begin{array}{c}-0.007 \\
(0.023)\end{array}$ & -0.001 \\
\hline Year of Mortgage Origination FE & No & & No & & Yes & & Yes & \\
\hline Observations & 632 & & 632 & & 632 & & 632 & \\
\hline F-statistic of first stage & 13.700 & & 13.030 & & 10.350 & & 11.260 & \\
\hline LR chi2 & 73.969 & & 81.821 & & 115.839 & & 117.382 & \\
\hline
\end{tabular}

Note: Table shows IV probit model estimates and average marginal effects. $* \mathrm{p}<0.1, * * \mathrm{p}<0.05, * * * \mathrm{p}<0.01$. Standard errors in parentheses. Sample includes all mortgage holders. 'Financial literacy' is instrumented with 'math level at school' which is a categorical variable taking a value between 0 and 5, where 0 is lowest math level at school and 5 is highest. The first-stage regression and baseline probit model are shown in Table A2. The baseline predicted probability is the average predicted likelihood from the model.

We show results of likelihood-ratio tests against the baseline specification (1) to evaluate the explanatory power of the other three models. Table A11 shows likelihood ratio tests comparing all specifications against each other.

Further controls for age, (spouse) employment status, household income, education leaving age, gender, marital status and dependent children. Table A9 shows the complete results of all variables. 
Table 7: Interest Rate Type Models

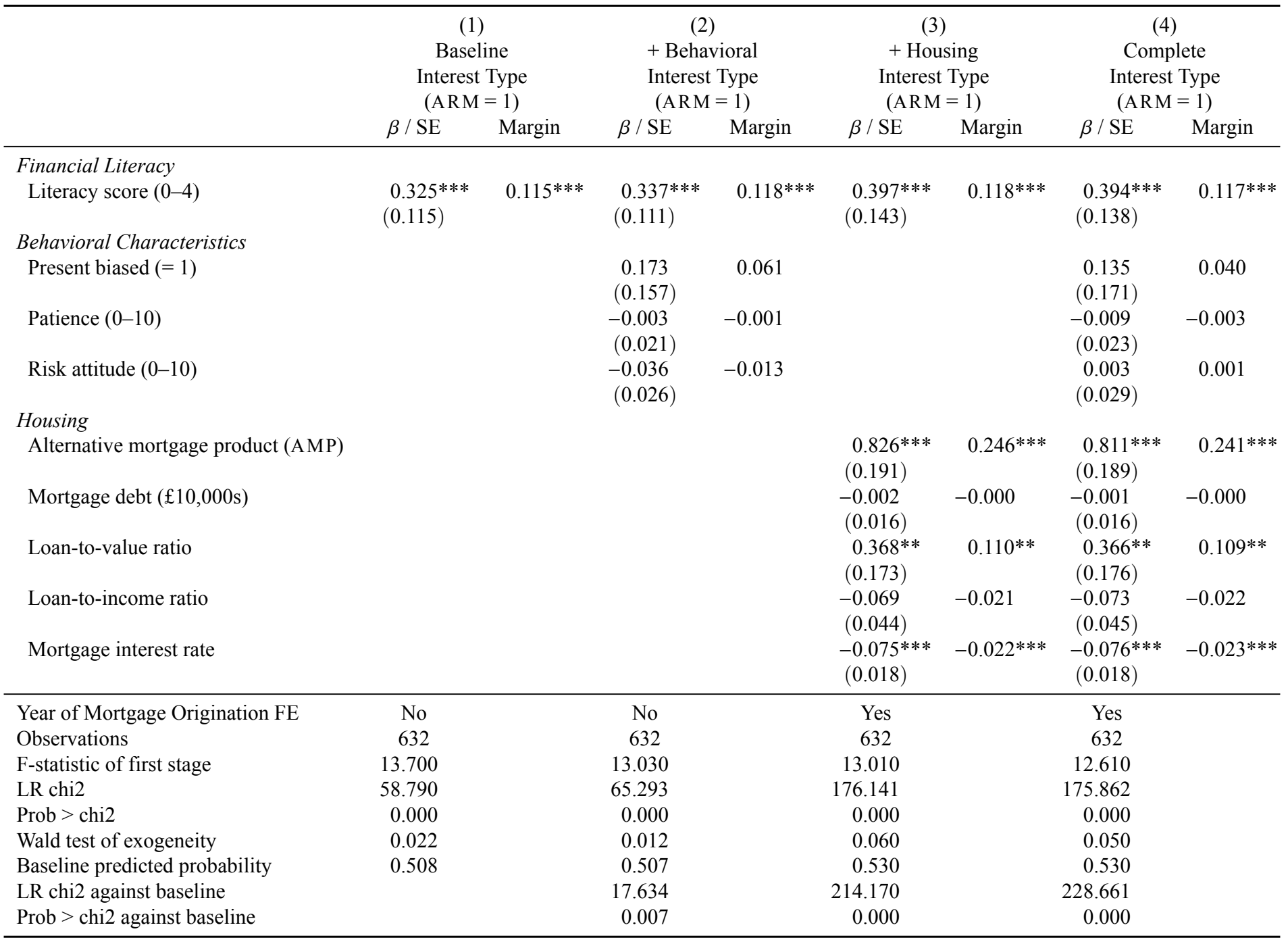

Note: Table shows IV probit model estimates and average marginal effects. $* \mathrm{p}<0.1, * * \mathrm{p}<0.05, * * * \mathrm{p}<0.01$. Standard errors in parentheses. Sample includes all mortgage holders. 'Financial literacy' is instrumented with 'math level at school' which is a categorical variable taking a value between 0 and 5, where 0 is lowest math level at school and 5 is highest. The first-stage regression and baseline probit model are shown in Table A2. The baseline predicted probability is the average predicted likelihood from the model.

We show results of likelihood-ratio tests against the baseline specification (1) to evaluate the explanatory power of the other three models. Table A11 shows likelihood ratio tests comparing all specifications against each other.

Further controls for age, (spouse) employment status, household income, education leaving age, gender, marital status and dependent children. Table A10 shows the complete results of all variables. 
Table 8: Extrapolation Bias

\begin{tabular}{|c|c|c|c|c|}
\hline & \multicolumn{2}{|c|}{$\begin{array}{c}(1) \\
\text { Repayment Type } \\
(\mathrm{AMP}=1)\end{array}$} & \multicolumn{2}{|c|}{$\begin{array}{c}(2) \\
\text { Interest Type } \\
(\mathrm{ARM}=1)\end{array}$} \\
\hline & $\beta / \mathrm{SE}$ & Margin & $\beta / \mathrm{SE}$ & Margin \\
\hline \multicolumn{5}{|l|}{ Financial Literacy } \\
\hline Literacy score $(0-4)$ & $\begin{array}{l}-0.520 * * * \\
(0.172)\end{array}$ & $-0.110 * * *$ & $\begin{array}{l}0.561 * * * \\
(0.112)\end{array}$ & $0.174 * * *$ \\
\hline \multicolumn{5}{|l|}{ Regional controls at time of origination } \\
\hline 3-year growth of median house prices & $\begin{array}{l}0.009 * * \\
(0.004)\end{array}$ & $0.002 * *$ & $\begin{array}{c}0.007 * \\
(0.004)\end{array}$ & $0.002 *$ \\
\hline Regional rate of unemployment & $\begin{array}{c}0.002 \\
(0.052)\end{array}$ & 0.001 & $\begin{array}{l}-0.112 * * * \\
(0.042)\end{array}$ & $-0.035 * * *$ \\
\hline Year of Mortgage Origination FE & No & & No & \\
\hline Observations & 442 & & 442 & \\
\hline F-statistic of first stage & 8.910 & & 11.460 & \\
\hline LR chi2 & 60.623 & & 128.225 & \\
\hline Prob $>$ chi 2 & 0.000 & & 0.000 & \\
\hline Wald test of exogeneity & 0.688 & & 0.000 & \\
\hline Baseline predicted probability & 0.201 & & 0.507 & \\
\hline
\end{tabular}

Note: Table shows IV probit model estimates for repayment type (Column 1) and interest rate type (Column 2), with additional controls: i) the 3-year growth rate of median house prices in the locality in the period before the current mortgage was taken out; ii) the rate of unemployment in the locality in the year of origination. Origination year fixed effects are not included because of collinearity.

Due to data restrictions, the estimated sample only includes English and Welsh households. Additional control variables as in Table 6 and Table 7. 'Literacy score' is instrumented with 'math level in school' in all specifications.

$* \mathrm{p}<0.1, * * \mathrm{p}<0.05, * * * \mathrm{p}<0.01$. Standard errors in parentheses.

Table 9: Interest type with Term Premium

\begin{tabular}{|c|c|c|c|c|c|c|}
\hline & \multicolumn{6}{|c|}{ Interest Type $(\mathrm{ARM}=1)$} \\
\hline & \multicolumn{2}{|c|}{ (1) } & \multicolumn{2}{|c|}{ (2) } & \multicolumn{2}{|c|}{ (3) } \\
\hline & $\beta / \mathrm{SE}$ & Margin & $\beta / \mathrm{SE}$ & Margin & $\beta / \mathrm{SE}$ & Margin \\
\hline Literacy score $(0-4)$ & $\begin{array}{l}0.440 * * * \\
(0.119)\end{array}$ & $0.145 * * *$ & $\begin{array}{l}0.468^{* * * *} \\
(0.119)\end{array}$ & $0.147 * * *$ & $\begin{array}{l}0.778^{* * *} \\
(0.184)\end{array}$ & $0.237 * * *$ \\
\hline Term premium (in \%) & & & $\begin{array}{l}0.698^{* * * *} \\
(0.127)\end{array}$ & $0.219 * * *$ & $\begin{array}{r}-0.842 \\
(0.522)\end{array}$ & -0.257 \\
\hline Literacy score $\mathrm{x}$ Term premium & & & & & $\begin{array}{l}0.644 * * * \\
(0.191)\end{array}$ & $0.197 * * *$ \\
\hline Year of Mortgage Origination FE & No & & No & & No & \\
\hline Observations & 632 & & 632 & & 632 & \\
\hline F-statistic of first stage & 12.710 & & 12.360 & & 21.160 & \\
\hline LR chi2 & 109.428 & & 147.317 & & 189.457 & \\
\hline Prob $>$ chi 2 & 0.000 & & 0.000 & & 0.000 & \\
\hline Wald test of exogeneity & 0.009 & & 0.007 & & 0.007 & \\
\hline Baseline predicted probability & 0.532 & & 0.532 & & 0.521 & \\
\hline
\end{tabular}

Note: Table shows IV probit model estimates and average marginal effects for the interest type models. ${ }^{*} \mathrm{p}<0.1$, $* * \mathrm{p}<0.05, * * * \mathrm{p}<0.01$. Standard errors in parentheses. Specifications are identical to the full models in Table 6 and Table 7, but includes the term premium at the year of mortgage origination and an interaction term with financial literacy. The interaction is instrumented with the interaction of the level of math and the term premium. Further notes and controls as in Table 7. 
Table A1: Consumer Credit and Savings

\begin{tabular}{|c|c|c|c|c|c|c|}
\hline & \multicolumn{3}{|c|}{ High Cost Credit (HCC) } & \multicolumn{3}{|c|}{ Savings } \\
\hline & \multirow{2}{*}{\multicolumn{2}{|c|}{$\begin{array}{c}\text { (1) } \\
\text { Holds HCC }\end{array}$}} & \multirow{3}{*}{$\begin{array}{c}(2) \\
\log \text { of } \mathrm{HCC} \\
\beta / \mathrm{SE}\end{array}$} & \multirow{2}{*}{\multicolumn{2}{|c|}{$\begin{array}{c}\text { (3) } \\
\text { Holds Savings }\end{array}$}} & \multirow{3}{*}{$\begin{array}{c}(4) \\
\log \text { of Savings } \\
\beta / \mathrm{SE}\end{array}$} \\
\hline & & & & & & \\
\hline & $\beta / \mathrm{SE}$ & Margin & & $\beta / \mathrm{SE}$ & Margin & \\
\hline \multicolumn{7}{|l|}{ Behavioral Characteristics } \\
\hline Present biased $(=1)$ & $\begin{array}{l}0.505^{* * * *} \\
(0.161)\end{array}$ & $0.187 * * *$ & $\begin{array}{l}1.456^{* *} \\
(0.663)\end{array}$ & $\begin{array}{c}-0.538 * * * \\
(0.162)\end{array}$ & $-0.198 * * *$ & $\begin{array}{l}-1.740 * * * \\
(0.566)\end{array}$ \\
\hline Patience $(0-10)$ & $\begin{array}{c}0.032 \\
(0.021)\end{array}$ & 0.012 & $\begin{array}{c}0.091 \\
(0.097)\end{array}$ & $\begin{array}{c}0.035^{*} \\
(0.021)\end{array}$ & $0.013 *$ & $\begin{array}{c}0.037 \\
(0.088)\end{array}$ \\
\hline Risk attitude $(0-10)$ & $\begin{array}{c}0.034 \\
(0.026)\end{array}$ & 0.013 & $\begin{array}{c}-0.007 \\
(0.111)\end{array}$ & $\begin{array}{c}-0.003 \\
(0.026)\end{array}$ & -0.001 & $\begin{array}{c}-0.178 * \\
(0.106)\end{array}$ \\
\hline \multicolumn{7}{|l|}{ Household Finances } \\
\hline Household income $<£ 15000$ & $\begin{array}{c}-0.382 * \\
(0.229)\end{array}$ & $-0.142^{*}$ & $\begin{array}{c}0.385 \\
(0.990)\end{array}$ & $\begin{array}{c}-0.397 * \\
(0.234)\end{array}$ & $-0.146^{*}$ & $\begin{array}{l}-3.668 * * * \\
(0.772)\end{array}$ \\
\hline Household income $£ 15,000-£ 30,000$ & $\begin{array}{c}-0.125 \\
(0.149)\end{array}$ & -0.046 & $\begin{array}{c}0.065 \\
(0.650)\end{array}$ & $\begin{array}{c}-0.097 \\
(0.148)\end{array}$ & -0.036 & $\begin{array}{c}-1.226^{* *} \\
(0.594)\end{array}$ \\
\hline Household income $£ 45,000-£ 60,000$ & $\begin{array}{c}0.273 * \\
(0.151)\end{array}$ & $0.101 *$ & $\begin{array}{c}0.108 \\
(0.658)\end{array}$ & $\begin{array}{c}0.241 \\
(0.150)\end{array}$ & 0.089 & $\begin{array}{c}0.804 \\
(0.613)\end{array}$ \\
\hline Household income $£ 60,000-£ 75,000$ & $\begin{array}{l}0.445^{* *} \\
(0.202)\end{array}$ & $0.165 * *$ & $\begin{array}{c}-0.519 \\
(0.840)\end{array}$ & $\begin{array}{l}0.630^{* * * *} \\
(0.211)\end{array}$ & $0.232 * * *$ & $\begin{array}{l}2.530^{* * * *} \\
(0.754)\end{array}$ \\
\hline Household income $>£ 75,000$ & $\begin{array}{c}0.419 * \\
(0.218)\end{array}$ & $0.155^{*}$ & $\begin{array}{c}-1.718 * \\
(0.874)\end{array}$ & $\begin{array}{l}0.624 * * * \\
(0.221)\end{array}$ & $0.229 * * *$ & $\begin{array}{l}2.395^{* *} \\
(0.976)\end{array}$ \\
\hline Recent income loss $(=1)$ & $\begin{array}{c}0.157 \\
(0.154)\end{array}$ & 0.058 & $\begin{array}{c}-0.711 \\
(0.593)\end{array}$ & $\begin{array}{c}-0.089 \\
(0.157)\end{array}$ & -0.033 & $\begin{array}{c}-0.235 \\
(0.573)\end{array}$ \\
\hline Credit constrained $(=1)$ & $\begin{array}{c}0.426^{*} \\
(0.231)\end{array}$ & $0.158^{*}$ & $\begin{array}{l}3.268 * * * \\
(0.980)\end{array}$ & $\begin{array}{c}-0.381 * \\
(0.230)\end{array}$ & $-0.140^{*}$ & $\begin{array}{l}-2.443 * * * \\
(0.740)\end{array}$ \\
\hline \multicolumn{7}{|l|}{ Age } \\
\hline $18-34$ & $\begin{array}{c}-0.549 * * * \\
(0.180)\end{array}$ & $-0.203 * * *$ & $\begin{array}{c}-0.892 \\
(0.841)\end{array}$ & $\begin{array}{r}-0.198 \\
(0.180)\end{array}$ & -0.073 & $\begin{array}{c}-0.037 \\
(0.757)\end{array}$ \\
\hline $35-44$ & $\begin{array}{c}-0.218 \\
(0.177)\end{array}$ & -0.081 & $\begin{array}{c}-0.746 \\
(0.809)\end{array}$ & $\begin{array}{c}-0.138 \\
(0.177)\end{array}$ & -0.051 & $\begin{array}{c}0.120 \\
(0.726)\end{array}$ \\
\hline $45-54$ & $\begin{array}{c}-0.206 \\
(0.166)\end{array}$ & -0.076 & $\begin{array}{c}-1.207^{*} \\
(0.686)\end{array}$ & $\begin{array}{c}-0.068 \\
(0.167)\end{array}$ & -0.025 & $\begin{array}{c}0.743 \\
(0.666)\end{array}$ \\
\hline \multicolumn{7}{|l|}{ Demographics } \\
\hline Male $(=1)$ & $\begin{array}{c}-0.001 \\
(0.111)\end{array}$ & -0.000 & $\begin{array}{c}-0.901^{*} \\
(0.490)\end{array}$ & $\begin{array}{c}0.166 \\
(0.111)\end{array}$ & 0.061 & $\begin{array}{c}0.750 * \\
(0.451)\end{array}$ \\
\hline Married/living as married $(=1)$ & $\begin{array}{l}-0.729 * * * \\
(0.239)\end{array}$ & $-0.270 * * *$ & $\begin{array}{c}0.433 \\
(1.157)\end{array}$ & $\begin{array}{c}-0.693 * * * \\
(0.233)\end{array}$ & $-0.255^{* * *}$ & $\begin{array}{c}0.175 \\
(1.082)\end{array}$ \\
\hline Dependent children $(=1)$ & $\begin{array}{c}0.113 \\
(0.125)\end{array}$ & 0.042 & $\begin{array}{c}0.875 \\
(0.575)\end{array}$ & $\begin{array}{c}-0.091 \\
(0.125)\end{array}$ & -0.033 & $\begin{array}{c}-0.402 \\
(0.515)\end{array}$ \\
\hline \multicolumn{7}{|l|}{ Employment } \\
\hline Employed (= 1) & $\begin{array}{c}-0.290 * \\
(0.172)\end{array}$ & $-0.107 *$ & $\begin{array}{c}1.070 \\
(0.703)\end{array}$ & $\begin{array}{c}0.078 \\
(0.172)\end{array}$ & 0.029 & $\begin{array}{c}-0.924 \\
(0.705)\end{array}$ \\
\hline Unemployed $(=1)$ & $\begin{array}{c}-0.169 \\
(0.559)\end{array}$ & -0.063 & $\begin{array}{c}-1.303 \\
(1.105)\end{array}$ & $\begin{array}{c}0.091 \\
(0.593)\end{array}$ & 0.034 & $\begin{array}{c}1.369 \\
(1.919)\end{array}$ \\
\hline Observations & 632 & & 296 & 632 & & 395 \\
\hline Pseudo $R^{2} / R^{2}$ & 0.063 & & 0.130 & 0.072 & & 0.169 \\
\hline LR chi2 / F & 55.093 & & 3.177 & 63.399 & & 5.921 \\
\hline Prob $>$ chi $2 / F$ & 0.000 & & 0.000 & 0.000 & & 0.000 \\
\hline Baseline predicted probability & 0.472 & & 2.818 & 0.504 & & 4.673 \\
\hline
\end{tabular}

Note: Columns 1 and 3 show probit estimates and average marginal effects on whether respondents hold high cost credit and savings, respectively. Columns 2 and 4 show results of OLS models with robust standard errors on the balances of high cost credit and savings, respectively, conditional on holding those balances. $* \mathrm{p}<0.1, * * \mathrm{p}<0.05, * * * \mathrm{p}<0.01$. 'High cost credit' is defined as holding two credit/store cards or more or holding a payday loan, pawn broker loan or home collected credit. 'Savings' are liquid savings in excess of $£ 250$. Additional controls for spouse employment status. Omitted reference group for age is 55+; for income $£ 30,000-£ 45,000$; for employment Retired/Student/Housewife/Disabled. 
Table A2: First-stage and non-instrumented Probit Models

\begin{tabular}{|c|c|c|c|c|c|c|}
\hline & \multicolumn{3}{|c|}{ Repayment Type } & \multicolumn{3}{|c|}{ Interest Type } \\
\hline & \multirow{4}{*}{$\begin{array}{c}(1) \\
\text { First Stage } \\
\text { Regression } \\
\beta / \mathrm{SE}\end{array}$} & \multirow{3}{*}{\multicolumn{2}{|c|}{$\begin{array}{c}(2) \\
\text { Probit } \\
(\mathrm{AMP}=1)\end{array}$}} & \multirow{4}{*}{$\begin{array}{l}\quad(3) \\
\text { First Stage } \\
\text { Regression } \\
\quad \beta / \mathrm{SE}\end{array}$} & \multirow{3}{*}{\multicolumn{2}{|c|}{$\begin{array}{c}(4) \\
\text { Probit } \\
(\mathrm{ARM}=1)\end{array}$}} \\
\hline & & & & & & \\
\hline & & & & & & \\
\hline & & $\beta / \mathrm{SE}$ & Margin & & $\beta / \mathrm{SE}$ & Margin \\
\hline \multicolumn{7}{|l|}{ Instrument } \\
\hline Math level in school (1-5) & $0.437 * * *$ & & & $0.386^{* * *}$ & & \\
\hline & $(0.050)$ & & & $(0.047)$ & & \\
\hline \multicolumn{7}{|l|}{ Financial Literacy } \\
\hline Literacy score $(0-4)$ & & $\begin{array}{c}-0.515 * * * \\
(0.061)\end{array}$ & $-0.107 * * *$ & & $\begin{array}{l}0.117 * * \\
(0.052)\end{array}$ & $0.036^{* *}$ \\
\hline \multicolumn{7}{|l|}{ Behavioral Characteristics } \\
\hline Present biased $(=1)$ & $\begin{array}{c}-0.208 \\
(0.138)\end{array}$ & $\begin{array}{l}0.509^{* * *} \\
(0.188)\end{array}$ & $0.106 * * *$ & $\begin{array}{c}-0.068 \\
(0.131)\end{array}$ & $\begin{array}{c}0.120 \\
(0.175)\end{array}$ & 0.037 \\
\hline Patience $(0-10)$ & $\begin{array}{c}-0.043 * * \\
(0.019)\end{array}$ & $\begin{array}{c}0.006 \\
(0.028)\end{array}$ & 0.001 & $\begin{array}{c}-0.036^{* *} \\
(0.018)\end{array}$ & $\begin{array}{c}-0.019 \\
(0.023)\end{array}$ & -0.006 \\
\hline Risk attitude $(0-10)$ & $\begin{array}{c}-0.038^{*} \\
(0.023)\end{array}$ & $\begin{array}{c}-0.068^{* *} \\
(0.034)\end{array}$ & $-0.014 * *$ & $\begin{array}{c}-0.049^{* *} \\
(0.022)\end{array}$ & $\begin{array}{c}-0.008 \\
(0.029)\end{array}$ & -0.002 \\
\hline \multicolumn{7}{|l|}{ Housing } \\
\hline Adjustable rate mortgage (ARM) & $\begin{array}{c}0.020 \\
(0.102)\end{array}$ & $\begin{array}{l}0.501 * * * \\
(0.151)\end{array}$ & $0.104 * * *$ & & & \\
\hline Alternative mortgage product (AMP) & & & & $\begin{array}{c}-0.929 * * * \\
(0.111)\end{array}$ & $\begin{array}{l}0.548 * * * \\
(0.157)\end{array}$ & $0.168^{* * *}$ \\
\hline Mortgage debt $(£ 10,000 \mathrm{~s})$ & $\begin{array}{c}-0.005 \\
(0.013)\end{array}$ & $\begin{array}{l}0.045^{* *} \\
(0.019)\end{array}$ & $0.009 * *$ & $\begin{array}{c}0.004 \\
(0.012)\end{array}$ & $\begin{array}{c}0.002 \\
(0.016)\end{array}$ & 0.001 \\
\hline Loan-to-value ratio & $\begin{array}{c}-0.248^{*} \\
(0.133)\end{array}$ & $\begin{array}{c}-0.151 \\
(0.206)\end{array}$ & -0.031 & $\begin{array}{c}-0.236^{*} \\
(0.125)\end{array}$ & $\begin{array}{c}0.320^{*} \\
(0.182)\end{array}$ & $0.098^{*}$ \\
\hline Loan-to-income ratio & $\begin{array}{c}0.047 \\
(0.037)\end{array}$ & $\begin{array}{c}-0.026 \\
(0.063)\end{array}$ & -0.005 & $\begin{array}{c}0.037 \\
(0.035)\end{array}$ & $\begin{array}{c}-0.069 \\
(0.047)\end{array}$ & -0.021 \\
\hline Mortgage interest rate & $\begin{array}{c}-0.002 \\
(0.014)\end{array}$ & $\begin{array}{c}-0.007 \\
(0.023)\end{array}$ & -0.002 & $\begin{array}{c}-0.005 \\
(0.013)\end{array}$ & $\begin{array}{c}-0.083 * * * \\
(0.018)\end{array}$ & $-0.025^{* * *}$ \\
\hline \multicolumn{7}{|l|}{ Household Finances } \\
\hline Recent income loss $(=1)$ & $\begin{array}{c}-0.286^{* *} \\
(0.136)\end{array}$ & $\begin{array}{c}-0.145 \\
(0.188)\end{array}$ & -0.030 & $\begin{array}{c}-0.285^{* *} \\
(0.128)\end{array}$ & $\begin{array}{c}0.307^{*} \\
(0.172)\end{array}$ & $0.094 *$ \\
\hline Credit constrained $(=1)$ & $\begin{array}{c}-0.020 \\
(0.197)\end{array}$ & $\begin{array}{c}0.483^{*} \\
(0.269)\end{array}$ & $0.101^{*}$ & $\begin{array}{c}0.073 \\
(0.186)\end{array}$ & $\begin{array}{c}-0.031 \\
(0.243)\end{array}$ & -0.009 \\
\hline \multicolumn{7}{|l|}{ Age } \\
\hline $18-34$ & $\begin{array}{l}-0.110 \\
(0.172)\end{array}$ & $\begin{array}{c}-0.877 * * * \\
(0.255)\end{array}$ & $-0.183 * * *$ & $\begin{array}{c}-0.274^{*} \\
(0.164)\end{array}$ & $\begin{array}{c}0.102 \\
(0.216)\end{array}$ & 0.031 \\
\hline $35-44$ & $\begin{array}{c}0.144 \\
(0.158)\end{array}$ & $\begin{array}{c}-0.690^{* * *} \\
(0.229)\end{array}$ & $-0.144 * * *$ & $\begin{array}{c}-0.011 \\
(0.150)\end{array}$ & $\begin{array}{c}0.178 \\
(0.196)\end{array}$ & 0.054 \\
\hline $45-54$ & $\begin{array}{c}0.003 \\
(0.147) \\
\end{array}$ & $\begin{array}{c}-0.485^{* *} \\
(0.207) \\
\end{array}$ & $-0.101 * *$ & $\begin{array}{c}-0.113 \\
(0.139) \\
\end{array}$ & $\begin{array}{c}-0.037 \\
(0.180) \\
\end{array}$ & -0.011 \\
\hline Year of Mortgage Origination FE & Yes & Yes & & Yes & Yes & \\
\hline Observations & 632 & 632 & & 632 & 632 & \\
\hline LR F/chi2 & 11.260 & 194.072 & & 12.610 & 188.152 & \\
\hline Prob $>$ F/chi2 & 0.000 & 0.000 & & 0.000 & 0.000 & \\
\hline Baseline predicted probability & 2.347 & 0.220 & & 2.347 & 0.534 & \\
\hline
\end{tabular}

Note: Table shows first-stage regression results and the results of the non-instrumented probit models (where financial literacy is not instrumented) of the complete models of Table 6 (Columns 1 and 2) and Table 7 (Columns 3 and 4).

Omitted reference group for age is $55+$. Further controls for (spouse) employment status, household income, education leaving age, gender, marital status and dependent children. 
Table A3: Mortgage choice - Sample Split at Median Income

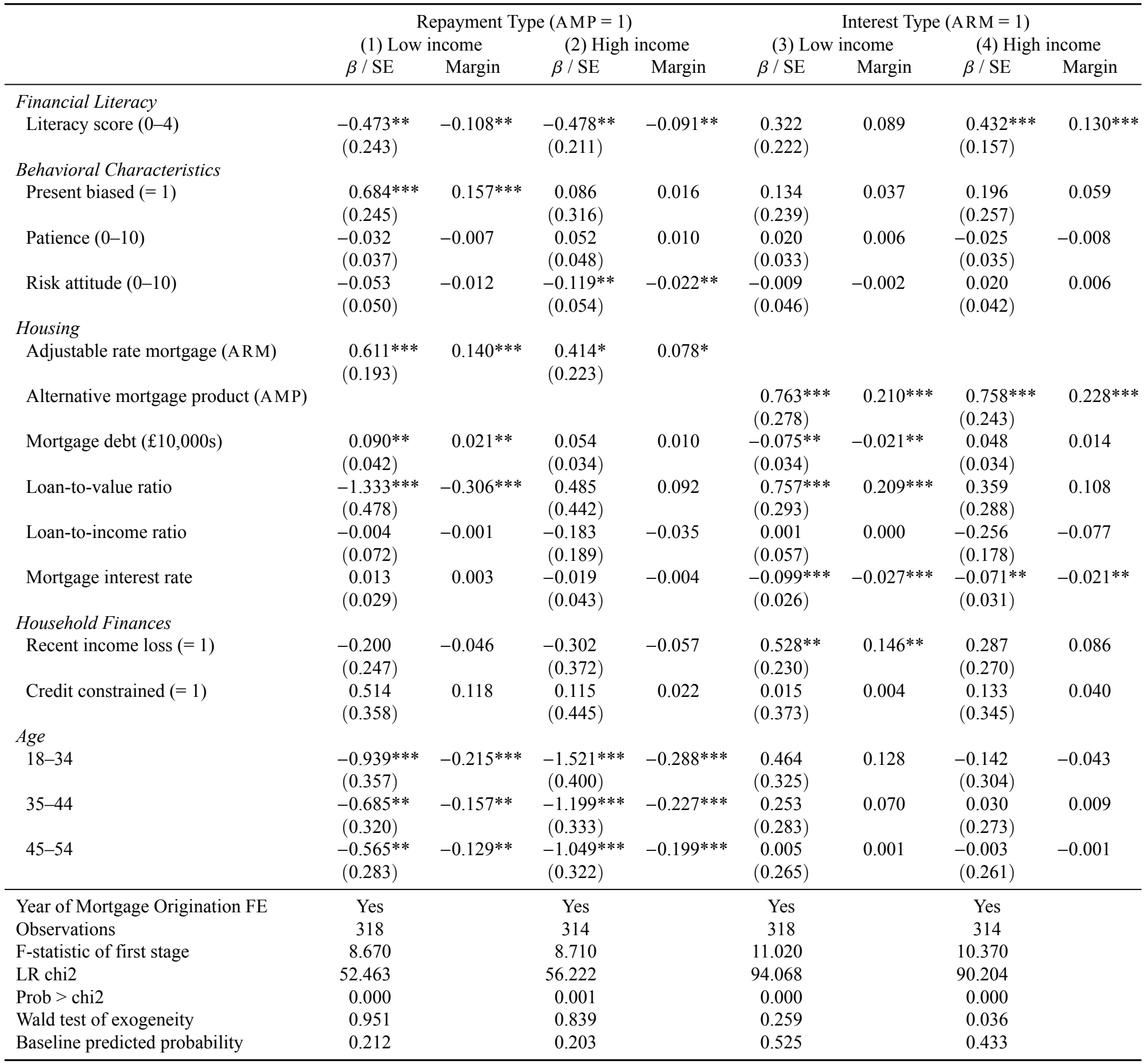

Note: Table shows IV probit model estimates and average marginal effects for the repayment-type models and interest-type models. The sample is split at the median income. Households at the median are included in the low-income group. $* \mathrm{p}<0.1, * * \mathrm{p}<0.05, * * * \mathrm{p}<0.01$. Standard errors in parentheses. Further notes apply as in Table 6 and Table 7.

Omitted reference group for age is 55+. Further controls for (spouse) employment status, household income, education leaving age, gender, marital status and dependent children. 
Table A4: Mortgage choice - Sample Split by Age Groups

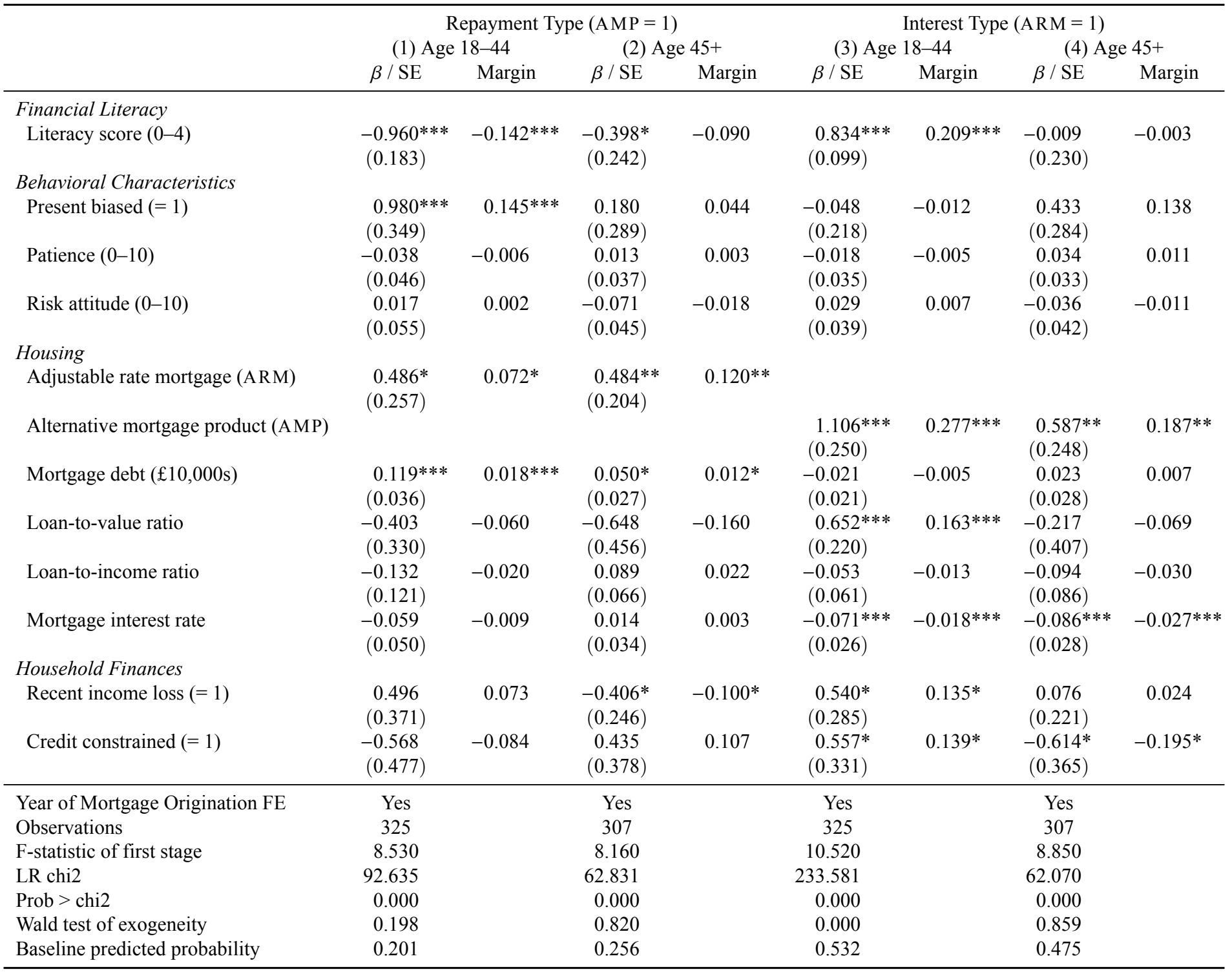

Note: Table shows IV probit model estimates and average marginal effects for the repayment-type models and interest-type models. The sample is split in two age groups: households age 18-44 and households age 45 and above. Households at the median are included in the low-income group. ${ }^{*} \mathrm{p}<0.1$, $* * \mathrm{p}<0.05, * * * \mathrm{p}<0.01$. Standard errors in parentheses. Further notes apply as in Table 6 and Table 7.

Controls for (spouse) employment status, household income, education leaving age, gender, marital status and dependent children. 
Table A5: Mortgage choice - Sample Split by refinancing in the last 3 years

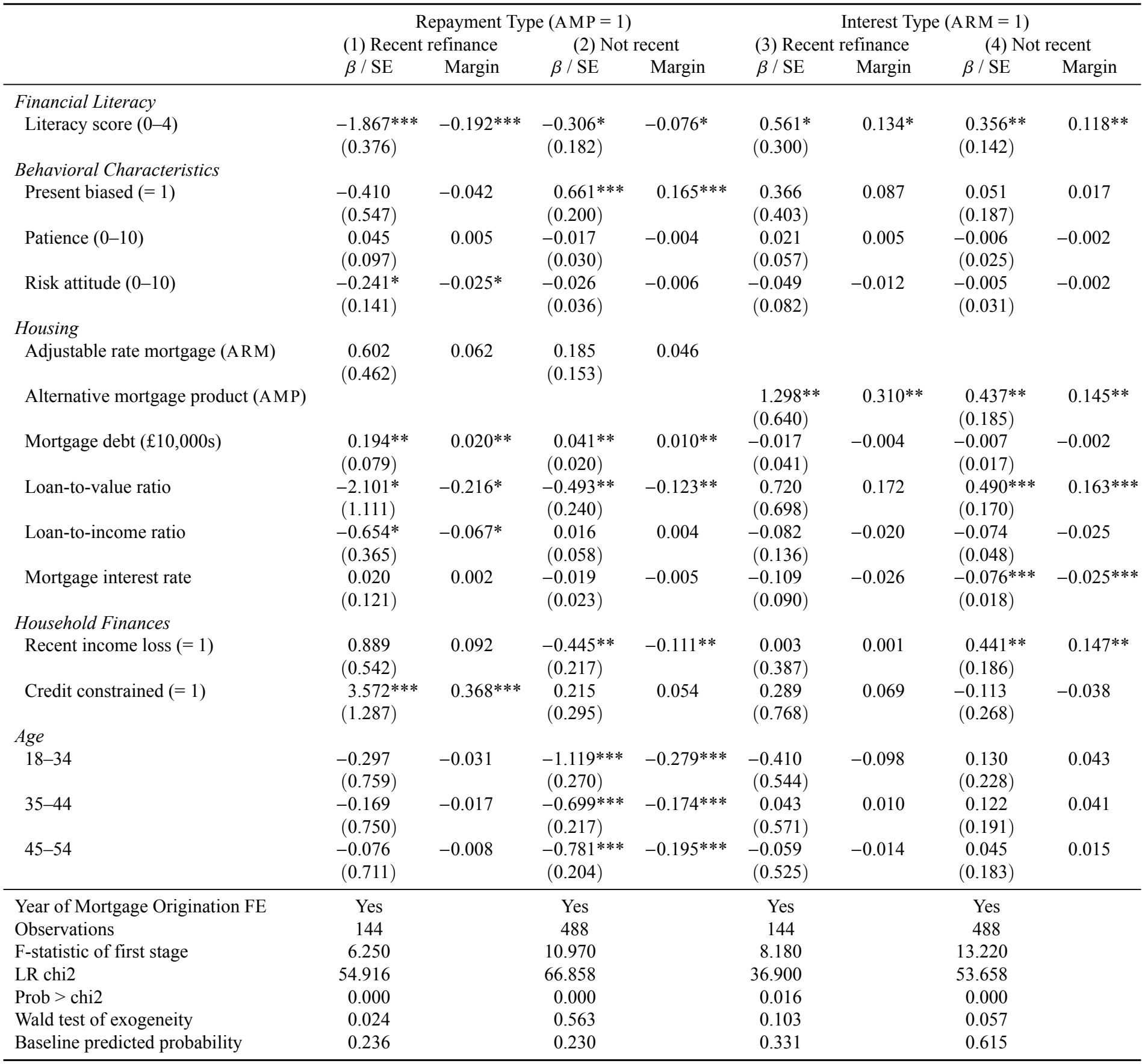

Note: Table shows IV probit model estimates and average marginal effects for the repayment-type models and interest-type models. The sample is split by whether the household refinanced their mortgage in the last 3 years. $* p<0.1, * * p<0.05, * * * p<0.01$. Standard errors in parentheses. Further notes apply as in Table 6 and Table 7.

Omitted reference group for age is 55+. Further controls for (spouse) employment status, household income, education leaving age, gender, marital status and dependent children. 
Table A6: Interaction of Financial Literacy and Credit Constrained for Repayment Models

Repayment Type $(\mathrm{AMP}=1)$

\begin{tabular}{|c|c|c|c|c|c|c|}
\hline & \multicolumn{2}{|c|}{ (1) Full Sample } & \multicolumn{2}{|c|}{ (2) Recent refinance } & \multicolumn{2}{|c|}{ (3) Not recent } \\
\hline & $\beta / \mathrm{SE}$ & Margin & $\beta / \mathrm{SE}$ & Margin & $\beta / \mathrm{SE}$ & Margin \\
\hline Literacy score $(0-4)$ & $\begin{array}{l}-0.564 * * * \\
(0.150)\end{array}$ & $-0.125^{* * *}$ & $\begin{array}{l}-1.452 * * * \\
(0.237)\end{array}$ & $-0.195 * * *$ & $\begin{array}{c}-0.386^{* *} \\
(0.166)\end{array}$ & $-0.102 * *$ \\
\hline Credit constrained $(=1)$ & $\begin{array}{r}-0.797 \\
(0.629)\end{array}$ & -0.177 & $\begin{array}{c}-2.209^{*} \\
(1.222)\end{array}$ & $-0.297 *$ & $\begin{array}{c}-0.497 \\
(0.699)\end{array}$ & -0.131 \\
\hline Literacy score $\mathrm{x}$ Credit constrained & $\begin{array}{c}0.448 * \\
(0.251)\end{array}$ & $0.099 *$ & $\begin{array}{l}1.545^{* * * *} \\
(0.487)\end{array}$ & $0.207 * * *$ & $\begin{array}{c}0.283 \\
(0.295)\end{array}$ & 0.075 \\
\hline Year of Mortgage Origination FE & Yes & & Yes & & Yes & \\
\hline Observations & 632 & & 144 & & 488 & \\
\hline F-statistic of first stage & 13.740 & & 6.490 & & 11.810 & \\
\hline LR chi2 & 99.387 & & 44.183 & & 39.936 & \\
\hline Prob $>$ chi2 & 0.000 & & 0.000 & & 0.000 & \\
\hline Wald test of exogeneity & 0.517 & & 0.160 & & 0.996 & \\
\hline Baseline predicted probability & 0.220 & & 0.141 & & 0.247 & \\
\hline
\end{tabular}

Note: Table shows IV probit model estimates and average marginal effects for the repayment type models. $* \mathrm{p}<0.1$, $* * \mathrm{p}<0.05, * * * \mathrm{p}<0.01$. Standard errors in parentheses. This specification includes an interaction term between financial literacy and an indicator variable denoting credit constraints. The interaction is instrumented with the interaction of the level of math and credit constraints. The sample in Column 1 comprises of all mortgage holders. In the remaining columns the sample is split by whether the household refinanced their mortgage in the last 3 years (Column 2) or not (Column 3). Further notes and control variables as in Table 6. 
Table A7: Robustness Models

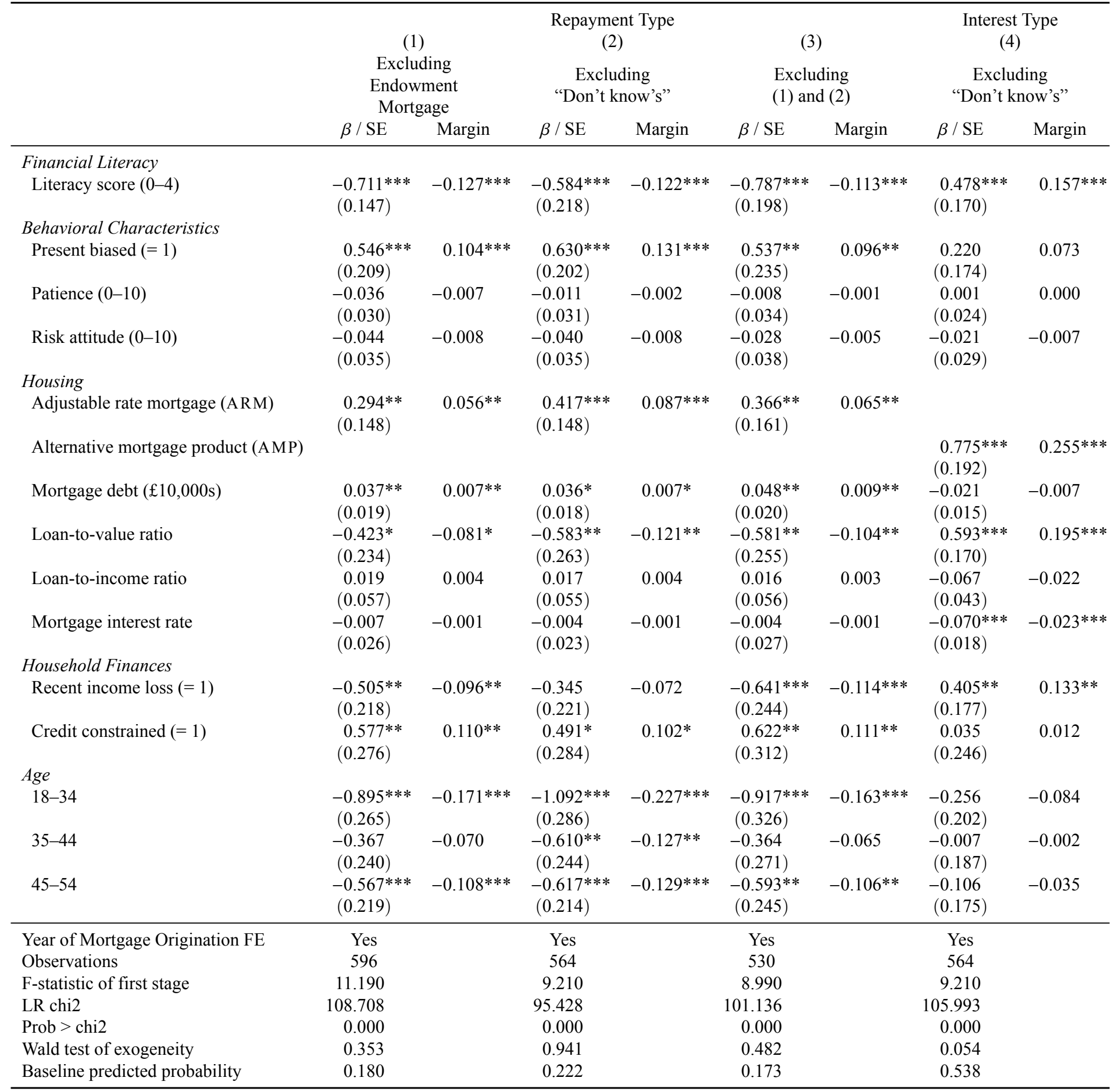

Note: Table shows IV probit model estimates and average marginal effects. 'Literacy score' is instrumented with 'math level in school' in all specifications. The estimated sample excludes respondents who have an endowment interest-only mortgage in Column 1. In Column 2, respondents are excluded who answered 'don't know' to the first literacy question or 'don't know' to three or more financial literacy questions. Column 3 combines the sample restrictions of Columns 1 and 2. Additional control variables as in Table $6 .{ }^{*} \mathrm{p}<0.1,{ }^{*} \mathrm{p}<0.05,{ }^{* * *} \mathrm{p}<0.01$. Standard errors in parentheses. Omitted reference group for age is 55+. Further controls for (spouse) employment status, household income, education leaving age, gender, marital status and dependent children. 
Table A8: Interaction of Financial Literacy and Present Bias

(a) Repayment Type (AMP =1)

\begin{tabular}{|c|c|c|c|c|c|c|}
\hline & \multicolumn{2}{|c|}{ (1) } & \multicolumn{2}{|c|}{ (2) } & \multicolumn{2}{|c|}{ (3) } \\
\hline & $\beta / \mathrm{SE}$ & Margin & $\beta / \mathrm{SE}$ & Margin & $\beta / \mathrm{SE}$ & Margin \\
\hline Literacy score $(0-4)$ & $\begin{array}{c}-0.579 * * * \\
(0.159)\end{array}$ & $-0.122 * * *$ & $\begin{array}{c}-0.578 * * * \\
(0.161)\end{array}$ & $-0.120 * * *$ & $\begin{array}{c}-0.619 * * * \\
(0.181)\end{array}$ & $-0.128 * * *$ \\
\hline Present biased $(=1)$ & & & $\begin{array}{l}0.491^{* *} \\
(0.193)\end{array}$ & $0.102 * *$ & $\begin{array}{c}-0.015 \\
(0.498)\end{array}$ & -0.003 \\
\hline Literacy score $\mathrm{x}$ Present biased & & & & & $\begin{array}{c}0.265 \\
(0.214)\end{array}$ & 0.055 \\
\hline Year of Mortgage Origination FE & Yes & & Yes & & Yes & \\
\hline Observations & 632 & & 632 & & 632 & \\
\hline F-statistic of first stage & 12.230 & & 11.690 & & 12.030 & \\
\hline LR chi2 & 111.665 & & 117.382 & & 120.304 & \\
\hline Prob $>$ chi 2 & 0.000 & & 0.000 & & 0.000 & \\
\hline Wald test of exogeneity & 0.683 & & 0.680 & & 0.678 & \\
\hline Baseline predicted probability & 0.227 & & 0.226 & & 0.227 & \\
\hline
\end{tabular}

(b) Interest Type (A RM =1)

\begin{tabular}{|c|c|c|c|c|c|c|}
\hline & \multicolumn{2}{|c|}{ (1) } & \multicolumn{2}{|c|}{ (2) } & \multicolumn{2}{|c|}{ (3) } \\
\hline & $\beta / \mathrm{SE}$ & Margin & $\beta / \mathrm{SE}$ & Margin & $\beta / \mathrm{SE}$ & Margin \\
\hline Literacy score $(0-4)$ & $\begin{array}{l}0.393 * * * \\
(0.138)\end{array}$ & $0.117 * * *$ & $\begin{array}{l}0.394 * * * \\
(0.138)\end{array}$ & $0.117 * * *$ & $\begin{array}{l}0.413^{* * *} \\
(0.154)\end{array}$ & $0.123^{* * *}$ \\
\hline Present biased $(=1)$ & & & $\begin{array}{c}0.135 \\
(0.171)\end{array}$ & 0.040 & $\begin{array}{c}0.442 \\
(0.418)\end{array}$ & 0.132 \\
\hline Literacy score $\mathrm{x}$ Present biased & & & & & $\begin{array}{c}-0.144 \\
(0.186) \\
\end{array}$ & -0.043 \\
\hline Year of Mortgage Origination FE & Yes & & Yes & & Yes & \\
\hline Observations & 632 & & 632 & & 632 & \\
\hline F-statistic of first stage & 15.380 & & 14.770 & & 16.240 & \\
\hline LR chi2 & 175.896 & & 175.862 & & 177.886 & \\
\hline Prob $>$ chi 2 & 0.000 & & 0.000 & & 0.000 & \\
\hline Wald test of exogeneity & 0.050 & & 0.050 & & 0.048 & \\
\hline Baseline predicted probability & 0.530 & & 0.530 & & 0.530 & \\
\hline
\end{tabular}

Note: Table shows IV probit model estimates and average marginal effects for the (a) repayment type models and (b) interest type models. $* \mathrm{p}<0.1,{ }^{* *} \mathrm{p}<0.05, * * * \mathrm{p}<0.01$. Standard errors in parentheses. Specifications are identical to the full models in Table 6 and Table 7, except that present bias and an interaction term between financial literacy and present bias are added separately. The interaction is instrumented with the interaction of the level of math and present bias. Further notes and controls as in Table 6 and Table 7. 
Table A9: Repayment Type Models: All variables

\begin{tabular}{|c|c|c|c|c|c|c|c|c|}
\hline & \multicolumn{2}{|c|}{$\begin{array}{c}(1) \\
\text { Baseline } \\
\text { Repayment Type } \\
(\mathrm{AMP}=1)\end{array}$} & \multicolumn{2}{|c|}{$\begin{array}{c}(2) \\
+ \text { Behavioral } \\
\text { Repayment Type } \\
(\text { AMP }=1)\end{array}$} & \multicolumn{2}{|c|}{$\begin{array}{c}(3) \\
+ \text { Housing } \\
\text { Repayment Type } \\
(\text { AMP }=1)\end{array}$} & \multicolumn{2}{|c|}{$\begin{array}{c}(4) \\
\text { Complete } \\
\text { Repayment Type } \\
(\mathrm{AMP}=1)\end{array}$} \\
\hline & $\beta / \mathrm{SE}$ & Margin & $\beta / \mathrm{SE}$ & Margin & $\beta / \mathrm{SE}$ & Margin & $\beta / \mathrm{SE}$ & Margin \\
\hline \multicolumn{9}{|l|}{ Financial Literacy } \\
\hline Literacy score $(0-4)$ & $\begin{array}{c}-0.454 * * * \\
(0.156)\end{array}$ & $-0.107 * * *$ & $\begin{array}{c}-0.428 * * * \\
(0.158)\end{array}$ & $-0.098 * * *$ & $\begin{array}{c}-0.609 * * * \\
(0.158)\end{array}$ & $-0.128 * * *$ & $\begin{array}{c}-0.578 * * * \\
(0.161)\end{array}$ & $-0.120 * * *$ \\
\hline \multicolumn{9}{|l|}{ Behavioral Characteristics } \\
\hline Present biased $(=1)$ & & & $\begin{array}{l}0.570^{* * * *} \\
(0.182)\end{array}$ & $0.131 * * *$ & & & $\begin{array}{l}0.491^{* *} \\
(0.193)\end{array}$ & $0.102 * *$ \\
\hline Patience $(0-10)$ & & & $\begin{array}{c}0.008 \\
(0.027)\end{array}$ & 0.002 & & & $\begin{array}{c}0.004 \\
(0.028)\end{array}$ & 0.001 \\
\hline Risk attitude $(0-10)$ & & & $\begin{array}{c}-0.079 * * \\
(0.032)\end{array}$ & $-0.018^{* *}$ & & & $\begin{array}{c}-0.069^{* *} \\
(0.034)\end{array}$ & $-0.014 * *$ \\
\hline \multicolumn{9}{|l|}{ Housing } \\
\hline Adjustable rate mortgage (ARM) & & & & & $\begin{array}{l}0.511 * * * \\
(0.148)\end{array}$ & $0.108 * * *$ & $\begin{array}{l}0.506^{* * * *} \\
(0.151)\end{array}$ & $0.105^{* * *}$ \\
\hline Mortgage debt $(£ 10,000 \mathrm{~s})$ & & & & & $\begin{array}{l}0.043^{* *} \\
(0.019)\end{array}$ & $0.009 * *$ & $\begin{array}{l}0.044^{* *} \\
(0.019)\end{array}$ & $0.009 * *$ \\
\hline Loan-to-value ratio & & & & & $\begin{array}{c}-0.167 \\
(0.209)\end{array}$ & -0.035 & $\begin{array}{c}-0.170 \\
(0.210)\end{array}$ & -0.035 \\
\hline Loan-to-income ratio & & & & & $\begin{array}{c}-0.017 \\
(0.062)\end{array}$ & -0.004 & $\begin{array}{c}-0.021 \\
(0.063)\end{array}$ & -0.004 \\
\hline Mortgage interest rate & & & & & $\begin{array}{c}-0.008 \\
(0.023)\end{array}$ & -0.002 & $\begin{array}{c}-0.007 \\
(0.023)\end{array}$ & -0.001 \\
\hline \multicolumn{9}{|l|}{ Year of Mortgage Origination } \\
\hline $2011-2012$ & & & & & $\begin{array}{c}-0.025 \\
(0.333)\end{array}$ & -0.005 & $\begin{array}{c}-0.013 \\
(0.339)\end{array}$ & -0.003 \\
\hline 2009-2010 & & & & & $\begin{array}{l}0.825^{* *} \\
(0.322)\end{array}$ & $0.174 * *$ & $\begin{array}{l}0.751 * * \\
(0.330)\end{array}$ & $0.156^{* *}$ \\
\hline $2007-2008$ & & & & & $\begin{array}{c}0.517 \\
(0.324)\end{array}$ & 0.109 & $\begin{array}{c}0.473 \\
(0.332)\end{array}$ & 0.098 \\
\hline 2003-2006 & & & & & $\begin{array}{c}0.456 \\
(0.302)\end{array}$ & 0.096 & $\begin{array}{c}0.412 \\
(0.308)\end{array}$ & 0.085 \\
\hline 1998-2002 & & & & & $\begin{array}{c}-0.040 \\
(0.342)\end{array}$ & -0.008 & $\begin{array}{c}-0.055 \\
(0.348)\end{array}$ & -0.011 \\
\hline before 1997 & & & & & $\begin{array}{l}0.729 * * \\
(0.320)\end{array}$ & $0.154 * *$ & $\begin{array}{l}0.705^{* *} \\
(0.327)\end{array}$ & $0.146^{* *}$ \\
\hline \multicolumn{9}{|l|}{ Age } \\
\hline $18-34$ & $\begin{array}{c}-0.930 * * * \\
(0.216)\end{array}$ & $-0.219 * * *$ & $\begin{array}{c}-1.013 * * * \\
(0.224)\end{array}$ & $-0.232 * * *$ & $\begin{array}{c}-0.798 * * * \\
(0.249)\end{array}$ & $-0.168 * * *$ & $\begin{array}{c}-0.869 * * * \\
(0.256)\end{array}$ & $-0.180^{* * *}$ \\
\hline $35-44$ & $\begin{array}{c}-0.647 * * * \\
(0.205)\end{array}$ & $-0.152 * * *$ & $\begin{array}{c}-0.775^{* * *} \\
(0.212)\end{array}$ & $-0.178 * * *$ & $\begin{array}{c}-0.559 * * \\
(0.225)\end{array}$ & $-0.118^{* *}$ & $\begin{array}{c}-0.673 * * * \\
(0.233)\end{array}$ & $-0.139 * * *$ \\
\hline $45-54$ & $\begin{array}{c}-0.590 * * * \\
(0.188)\end{array}$ & $-0.139 * * *$ & $\begin{array}{c}-0.666^{* * *} \\
(0.194)\end{array}$ & $-0.153 * * *$ & $\begin{array}{c}-0.407 * * \\
(0.200)\end{array}$ & $-0.086^{* *}$ & $\begin{array}{c}-0.480 * * \\
(0.207)\end{array}$ & $-0.099 * *$ \\
\hline \multicolumn{9}{|l|}{ Demographics } \\
\hline Male $(=1)$ & $\begin{array}{c}-0.042 \\
(0.148)\end{array}$ & -0.010 & $\begin{array}{c}0.022 \\
(0.154)\end{array}$ & 0.005 & $\begin{array}{c}0.049 \\
(0.161)\end{array}$ & 0.010 & $\begin{array}{c}0.111 \\
(0.168)\end{array}$ & 0.023 \\
\hline Married/living as married $(=1)$ & $\begin{array}{c}-0.041 \\
(0.290)\end{array}$ & -0.010 & $\begin{array}{c}-0.074 \\
(0.288)\end{array}$ & -0.017 & $\begin{array}{c}-0.219 \\
(0.315)\end{array}$ & -0.046 & $\begin{array}{c}-0.259 \\
(0.313)\end{array}$ & -0.054 \\
\hline Dependent children $(=1)$ & $\begin{array}{c}0.247 \\
(0.155)\end{array}$ & 0.058 & $\begin{array}{c}0.297 * \\
(0.159)\end{array}$ & $0.068 *$ & $\begin{array}{c}0.205 \\
(0.164)\end{array}$ & 0.043 & $\begin{array}{c}0.250 \\
(0.168)\end{array}$ & 0.052 \\
\hline Employment & & & & & & & & \\
\hline
\end{tabular}




\begin{tabular}{|c|c|c|c|c|c|c|c|c|}
\hline & \multicolumn{2}{|c|}{$\begin{array}{c}(1) \\
\text { Baseline } \\
\text { Repayment Type } \\
(\text { AMP = 1) }\end{array}$} & \multicolumn{2}{|c|}{$\begin{array}{c}(2) \\
+ \text { Behavioral } \\
\text { Repayment Type } \\
(\text { AMP }=1)\end{array}$} & \multicolumn{2}{|c|}{$\begin{array}{c}(3) \\
+ \text { Housing } \\
\text { Repayment Type } \\
(\text { AMP }=1)\end{array}$} & \multicolumn{2}{|c|}{$\begin{array}{c}(4) \\
\text { Complete } \\
\text { Repayment Type } \\
(\mathrm{AMP}=1)\end{array}$} \\
\hline & $\beta / \mathrm{SE}$ & Margin & $\beta / \mathrm{SE}$ & Margin & $\beta / \mathrm{SE}$ & Margin & $\beta / \mathrm{SE}$ & Margin \\
\hline Employed $(=1)$ & $\begin{array}{r}-0.296 \\
(0.195)\end{array}$ & -0.070 & $\begin{array}{c}-0.341 * \\
(0.197)\end{array}$ & $-0.078^{*}$ & $\begin{array}{r}-0.216 \\
(0.207)\end{array}$ & -0.046 & $\begin{array}{r}-0.256 \\
(0.210)\end{array}$ & -0.053 \\
\hline Unemployed $(=1)$ & $\begin{array}{c}0.113 \\
(0.622)\end{array}$ & 0.027 & $\begin{array}{c}-0.257 \\
(0.647)\end{array}$ & -0.059 & $\begin{array}{c}0.076 \\
(0.650)\end{array}$ & 0.016 & $\begin{array}{c}-0.187 \\
(0.671)\end{array}$ & -0.039 \\
\hline Spouse employed $(=1)$ & $\begin{array}{c}-0.272 \\
(0.282)\end{array}$ & -0.064 & $\begin{array}{r}-0.230 \\
(0.277)\end{array}$ & -0.053 & $\begin{array}{c}-0.057 \\
(0.307)\end{array}$ & -0.012 & $\begin{array}{r}-0.002 \\
(0.302)\end{array}$ & -0.000 \\
\hline Spouse unemployed & $\begin{array}{c}-0.211 \\
(0.509)\end{array}$ & -0.050 & $\begin{array}{c}-0.284 \\
(0.514)\end{array}$ & -0.065 & $\begin{array}{c}-0.001 \\
(0.536)\end{array}$ & -0.000 & $\begin{array}{c}-0.067 \\
(0.540)\end{array}$ & -0.014 \\
\hline Spouse retired & $\begin{array}{l}0.716^{* *} \\
(0.360)\end{array}$ & $0.169 * *$ & $\begin{array}{c}0.717 * * \\
(0.362)\end{array}$ & $0.164 * *$ & $\begin{array}{l}1.057 * * * \\
(0.390)\end{array}$ & $0.223 * * *$ & $\begin{array}{l}1.075^{* * *} \\
(0.391)\end{array}$ & $0.223 * * *$ \\
\hline \multicolumn{9}{|l|}{ Household Finances } \\
\hline Household income $<£ 15000$ & $\begin{array}{r}-0.054 \\
(0.265)\end{array}$ & -0.013 & $\begin{array}{r}-0.132 \\
(0.267)\end{array}$ & -0.030 & $\begin{array}{c}-0.041 \\
(0.341)\end{array}$ & -0.009 & $\begin{array}{r}-0.094 \\
(0.345)\end{array}$ & -0.019 \\
\hline Household income $£ 15,000-£ 30,000$ & $\begin{array}{c}0.281 \\
(0.195)\end{array}$ & 0.066 & $\begin{array}{c}0.266 \\
(0.195)\end{array}$ & 0.061 & $\begin{array}{c}0.274 \\
(0.223)\end{array}$ & 0.058 & $\begin{array}{c}0.274 \\
(0.223)\end{array}$ & 0.057 \\
\hline Household income $£ 45,000-£ 60,000$ & $\begin{array}{c}0.331 * \\
(0.188)\end{array}$ & $0.078 *$ & $\begin{array}{c}0.343^{*} \\
(0.190)\end{array}$ & $0.079 *$ & $\begin{array}{c}0.152 \\
(0.206)\end{array}$ & 0.032 & $\begin{array}{c}0.161 \\
(0.210)\end{array}$ & 0.033 \\
\hline Household income $£ 60,000-£ 75,000$ & $\begin{array}{l}0.580^{* *} \\
(0.258)\end{array}$ & $0.136^{* *}$ & $\begin{array}{l}0.653 * * \\
(0.263)\end{array}$ & $0.150 * *$ & $\begin{array}{c}0.360 \\
(0.285)\end{array}$ & 0.076 & $\begin{array}{c}0.419 \\
(0.290)\end{array}$ & 0.087 \\
\hline Household income $>£ 75,000$ & $\begin{array}{c}0.140 \\
(0.275)\end{array}$ & 0.033 & $\begin{array}{c}0.136 \\
(0.285)\end{array}$ & 0.031 & $\begin{array}{c}-0.394 \\
(0.369)\end{array}$ & -0.083 & $\begin{array}{r}-0.414 \\
(0.380)\end{array}$ & -0.086 \\
\hline Recent income loss $(=1)$ & $\begin{array}{c}-0.019 \\
(0.184)\end{array}$ & -0.004 & $\begin{array}{c}-0.017 \\
(0.186)\end{array}$ & -0.004 & $\begin{array}{c}-0.176 \\
(0.195)\end{array}$ & -0.037 & $\begin{array}{c}-0.168 \\
(0.196)\end{array}$ & -0.035 \\
\hline Credit constrained $(=1)$ & $\begin{array}{c}0.443^{*} \\
(0.254)\end{array}$ & $0.104 *$ & $\begin{array}{c}0.456^{*} \\
(0.260)\end{array}$ & $0.104 *$ & $\begin{array}{c}0.454 * \\
(0.265)\end{array}$ & $0.096^{*}$ & $\begin{array}{c}0.478 * \\
(0.269)\end{array}$ & $0.099^{*}$ \\
\hline
\end{tabular}

Note: Table shows all included variables of the IV probit models estimated in Table 6. The same notes apply. The base for mortgage origination is the year 2013 . 
Table A10: Interest Type Models: All variables

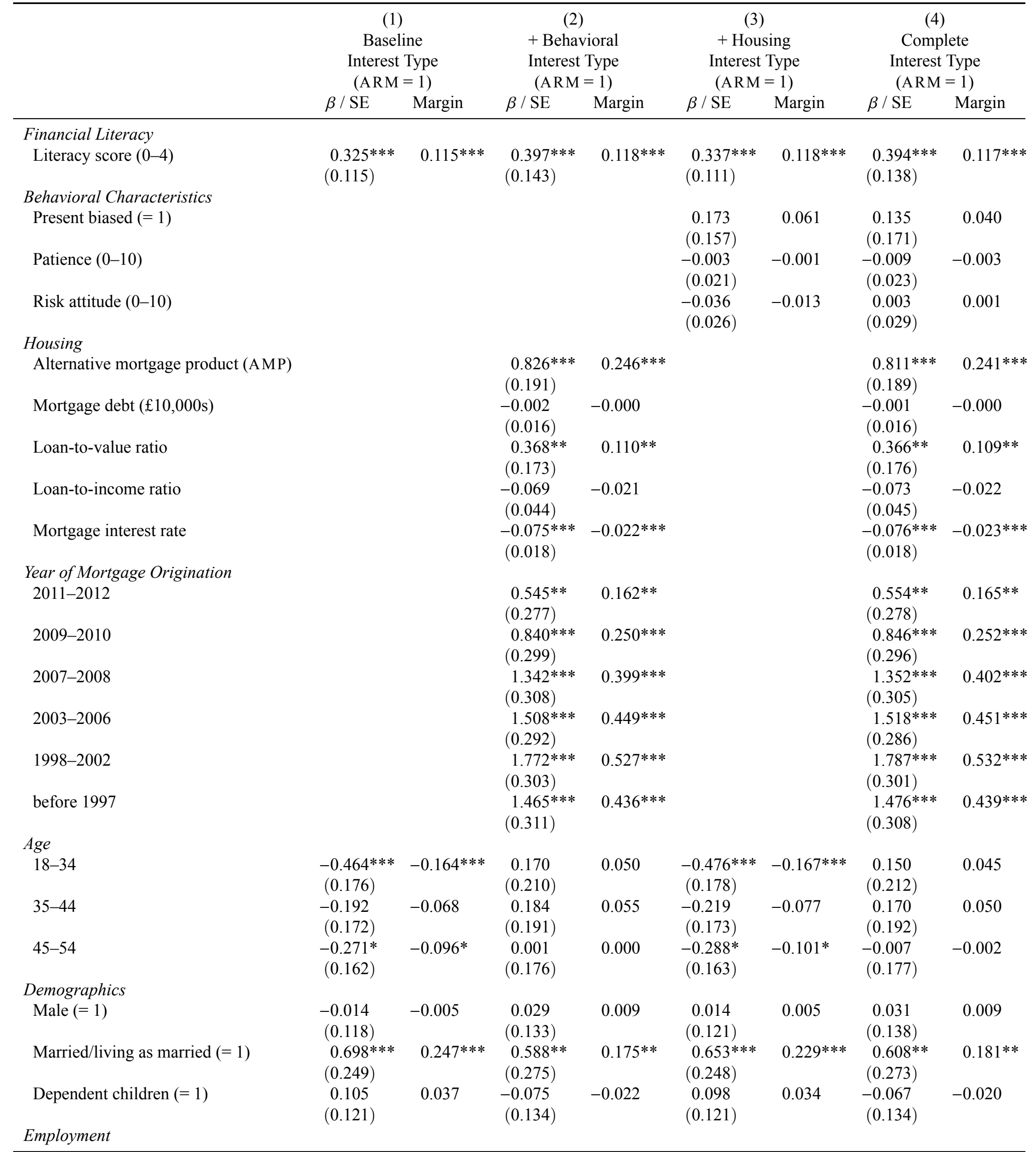




\begin{tabular}{|c|c|c|c|c|c|c|c|c|}
\hline & \multicolumn{2}{|c|}{$\begin{array}{c}(1) \\
\text { Baseline } \\
\text { Interest Type } \\
(\mathrm{ARM}=1)\end{array}$} & \multicolumn{2}{|c|}{$\begin{array}{c}(2) \\
+ \text { Behavioral } \\
\text { Interest Type } \\
(\mathrm{ARM}=1)\end{array}$} & \multicolumn{2}{|c|}{$\begin{array}{c}(3) \\
+ \text { Housing } \\
\text { Interest Type } \\
(\mathrm{ARM}=1)\end{array}$} & \multicolumn{2}{|c|}{$\begin{array}{c}(4) \\
\text { Complete } \\
\text { Interest Type } \\
(\mathrm{ARM}=1)\end{array}$} \\
\hline & $\beta / \mathrm{SE}$ & Margin & $\beta / \mathrm{SE}$ & Margin & $\beta / \mathrm{SE}$ & Margin & $\beta / \mathrm{SE}$ & Margin \\
\hline Employed (= 1) & $\begin{array}{c}-0.069 \\
(0.169)\end{array}$ & -0.024 & $\begin{array}{c}0.064 \\
(0.183)\end{array}$ & 0.019 & $\begin{array}{c}-0.071 \\
(0.169)\end{array}$ & -0.025 & $\begin{array}{c}0.057 \\
(0.183)\end{array}$ & 0.017 \\
\hline Unemployed (= 1) & $\begin{array}{c}0.059 \\
(0.629)\end{array}$ & 0.021 & $\begin{array}{c}-0.077 \\
(0.657)\end{array}$ & -0.023 & $\begin{array}{c}-0.088 \\
(0.620)\end{array}$ & -0.031 & $\begin{array}{c}-0.162 \\
(0.653)\end{array}$ & -0.048 \\
\hline Spouse employed $(=1)$ & $\begin{array}{c}-0.551^{* *} \\
(0.238)\end{array}$ & $-0.195^{* *}$ & $\begin{array}{c}-0.293 \\
(0.264)\end{array}$ & -0.087 & $\begin{array}{c}-0.490^{* *} \\
(0.235)\end{array}$ & $-0.172 * *$ & $\begin{array}{c}-0.311 \\
(0.259)\end{array}$ & -0.092 \\
\hline Spouse unemployed & $\begin{array}{c}-0.264 \\
(0.448)\end{array}$ & -0.093 & $\begin{array}{c}0.235 \\
(0.482)\end{array}$ & 0.070 & $\begin{array}{c}-0.243 \\
(0.445)\end{array}$ & -0.085 & $\begin{array}{c}0.195 \\
(0.483)\end{array}$ & 0.058 \\
\hline Spouse retired & $\begin{array}{c}-0.813 * * \\
(0.331)\end{array}$ & $-0.287^{* *}$ & $\begin{array}{c}-0.765^{* *} \\
(0.361)\end{array}$ & $-0.228 * *$ & $\begin{array}{c}-0.778^{* *} \\
(0.331)\end{array}$ & $-0.273 * *$ & $\begin{array}{c}-0.774 * * \\
(0.363)\end{array}$ & $-0.230 * *$ \\
\hline \multicolumn{9}{|l|}{ Household Finances } \\
\hline Household income $<£ 15000$ & $\begin{array}{l}0.547^{* *} \\
(0.229)\end{array}$ & $0.193^{* *}$ & $\begin{array}{l}0.825^{* * *} \\
(0.294)\end{array}$ & $0.245 * * *$ & $\begin{array}{l}0.521^{* *} \\
(0.229)\end{array}$ & $0.183^{* *}$ & $\begin{array}{l}0.830^{* * *} \\
(0.297)\end{array}$ & $0.247^{* * *}$ \\
\hline Household income $£ 15,000-£ 30,000$ & $\begin{array}{c}0.134 \\
(0.163)\end{array}$ & 0.047 & $\begin{array}{c}0.243 \\
(0.179)\end{array}$ & 0.072 & $\begin{array}{c}0.126 \\
(0.161)\end{array}$ & 0.044 & $\begin{array}{c}0.248 \\
(0.179)\end{array}$ & 0.074 \\
\hline Household income $£ 45,000-£ 60,000$ & $\begin{array}{c}0.145 \\
(0.146)\end{array}$ & 0.051 & $\begin{array}{c}0.139 \\
(0.166)\end{array}$ & 0.041 & $\begin{array}{c}0.141 \\
(0.147)\end{array}$ & 0.050 & $\begin{array}{c}0.142 \\
(0.167)\end{array}$ & 0.042 \\
\hline Household income $£ 60,000-£ 75,000$ & $\begin{array}{c}0.015 \\
(0.206)\end{array}$ & 0.005 & $\begin{array}{c}-0.163 \\
(0.240)\end{array}$ & -0.049 & $\begin{array}{c}0.026 \\
(0.206)\end{array}$ & 0.009 & $\begin{array}{c}-0.162 \\
(0.241)\end{array}$ & -0.048 \\
\hline Household income $>£ 75,000$ & $\begin{array}{c}-0.015 \\
(0.209)\end{array}$ & -0.005 & $\begin{array}{c}-0.034 \\
(0.272)\end{array}$ & -0.010 & $\begin{array}{c}0.010 \\
(0.210)\end{array}$ & 0.003 & $\begin{array}{c}-0.044 \\
(0.275)\end{array}$ & -0.013 \\
\hline Recent income loss $(=1)$ & $\begin{array}{c}0.303^{*} \\
(0.156)\end{array}$ & $0.107^{*}$ & $\begin{array}{l}0.388^{* *} \\
(0.170)\end{array}$ & $0.115^{* *}$ & $\begin{array}{l}0.312^{* *} \\
(0.155)\end{array}$ & $0.109 * *$ & $\begin{array}{c}0.380^{* *} \\
(0.170)\end{array}$ & $0.113^{* *}$ \\
\hline Credit constrained $(=1)$ & $\begin{array}{c}-0.050 \\
(0.221)\end{array}$ & -0.018 & $\begin{array}{c}-0.050 \\
(0.235)\end{array}$ & -0.015 & $\begin{array}{c}-0.036 \\
(0.222)\end{array}$ & -0.013 & $\begin{array}{c}-0.062 \\
(0.237)\end{array}$ & -0.019 \\
\hline
\end{tabular}

Note: Table shows all included variables of the IV probit models estimated in Table 7 . The same notes apply. The base for mortgage origination is the year 2013. 
Table A11: Likelihood-ratio tests

(a) Repayment Type Models

\begin{tabular}{lccc}
\hline & (2)+ Behavioral & (3) + Housing & (4) Complete \\
\hline (1) Baseline & $17.24^{* * *}$ & $52.40^{* * *}$ & $69.82^{* * *}$ \\
(2) + Behavioral & & $35.17^{* *}$ & $52.58^{* * *}$ \\
(3) + Housing & & & $17.42^{* * *}$ \\
\hline
\end{tabular}

(b) Interest Type Models

\begin{tabular}{lccc}
\hline & $(2)+$ Behavioral & (3) + Housing & (4) Complete \\
\hline (1) Baseline & $17.38^{* * *}$ & $202.03^{* * *}$ & $214.91^{* * *}$ \\
(2) + Behavioral & & $184.65^{* * *}$ & $197.53^{* * *}$ \\
(3) + Housing & & & $12.88^{* *}$ \\
\hline
\end{tabular}

Note: Table shows results of the Likelihood-ratio tests comparing all model specifications shown in Table 6 (Panel A) and Table 7 (Panel B). $* \mathrm{p}<0.1,{ }^{* *} \mathrm{p}<0.05,{ }^{* * *} \mathrm{p}<0.01$ 